\title{
Does the East Greenland Current exist in the northern Fram Strait?
}

\author{
Maren Elisabeth Richter ${ }^{1, a}$, Wilken-Jon von Appen $^{1}$, and Claudia Wekerle ${ }^{1}$ \\ ${ }^{1}$ Alfred Wegener Institute, Helmholtz Centre for Polar and Marine Research, \\ Am Handelshafen 12, 27570 Bremerhaven, Germany \\ anow at: Department of Physics, University of Otago, 730 Cumberland Street, Dunedin 9016, New Zealand
}

Correspondence: Maren Elisabeth Richter (maren.richter@postgrad.otago.ac.nz)

Received: 20 April 2018 - Discussion started: 28 May 2018

Revised: 2 August 2018 - Accepted: 31 August 2018 - Published: 27 September 2018

\begin{abstract}
Warm Atlantic Water (AW) flows around the Nordic Seas in a cyclonic boundary current loop. Some AW enters the Arctic Ocean where it is transformed to Arctic Atlantic Water (AAW) before exiting through the Fram Strait. There the AAW is joined by recirculating AW. Here we present the first summer synoptic study targeted at resolving this confluence in the Fram Strait which forms the East Greenland Current (EGC). Absolute geostrophic velocities and hydrography from observations in 2016, including four sections crossing the east Greenland shelf break, are compared to output from an eddy-resolving configuration of the sea ice-ocean model FESOM. Far offshore $(120 \mathrm{~km}$ at $80.8^{\circ} \mathrm{N}$ ) AW warmer than $2{ }^{\circ} \mathrm{C}$ is found in the northern Fram Strait. The Arctic Ocean outflow there is broad and barotropic, but gets narrower and more baroclinic toward the south as recirculating AW increases the cross-shelf-break density gradient. This barotropic to baroclinic transition appears to form the well-known EGC boundary current flowing along the shelf break farther south where it has been previously described. In this realization, between 80.2 and $76.5^{\circ} \mathrm{N}$, the southward transport along the east Greenland shelf break increases from roughly $1 \mathrm{~Sv}$ to about $4 \mathrm{~Sv}$ and the proportion of AW to AAW also increases fourfold from $19 \pm 8 \%$ to $80 \pm 3 \%$. Consequently, in the southern Fram Strait, AW can propagate into the Norske Trough on the east Greenland shelf and reach the large marine-terminating glaciers there. High instantaneous variability observed in both the synoptic data and the model output is attributed to eddies, the representation of which is crucial as they mediate the westward transport of $\mathrm{AW}$ in the recirculation and thus structure the confluence forming the EGC.
\end{abstract}

\section{Introduction}

The Fram Strait, located between Greenland and Svalbard, is the only deep connection between the Arctic Ocean and the Nordic Seas. Pathways and modification of water masses there and on the northeast Greenland shelf are insufficiently understood. The northeast Greenland shelf is dominated by a C-shaped trough: the Westwind Trough and the Norske Trough cross the shelf break at $\sim 80.5^{\circ} \mathrm{N}$ and at $\sim 76.5^{\circ} \mathrm{N}$, respectively (Fig. 1). These allow exchange flows below $100 \mathrm{~m}$ depth between the outlet glaciers of the North East Greenland Ice Stream (NEGIS), the largest of which is the $79 \mathrm{~N}$ Glacier, and the deep Fram Strait. Thus, the troughs may provide a pathway for warm, saline waters of Atlantic origin to the glaciers where they contribute to submarine melt (Schaffer et al., 2017). Relatively warm (warmer than $2{ }^{\circ} \mathrm{C}$ ) and salty Atlantic Water (AW) enters the Nordic Seas across the Greenland-Scotland Ridge and flows in a cyclonic boundary current loop (Mauritzen, 1996) comprised of the northward flowing Norwegian Atlantic Current and West Spitsbergen Current (WSC) in the eastern Fram Strait (see Hanzlick, 1983, for a review of early studies of the WSC), and the southward flowing East Greenland Current (EGC, see Aagaard and Coachman, 1968, for a review of early observations of the EGC) in the western Fram Strait. During the loop through the Nordic Seas, AW is cooled and densified, forming part of the Denmark Strait Overflow Water (DSOW) which becomes the dense component of the North Atlantic Deep Water south of the Greenland-Scotland Ridge (Mauritzen, 1996; Rudels et al., 2002; Våge et al., 2013). Some AW enters the Arctic Ocean through the Barents Sea and the Fram Strait. AW flows cyclonically around the Arctic 


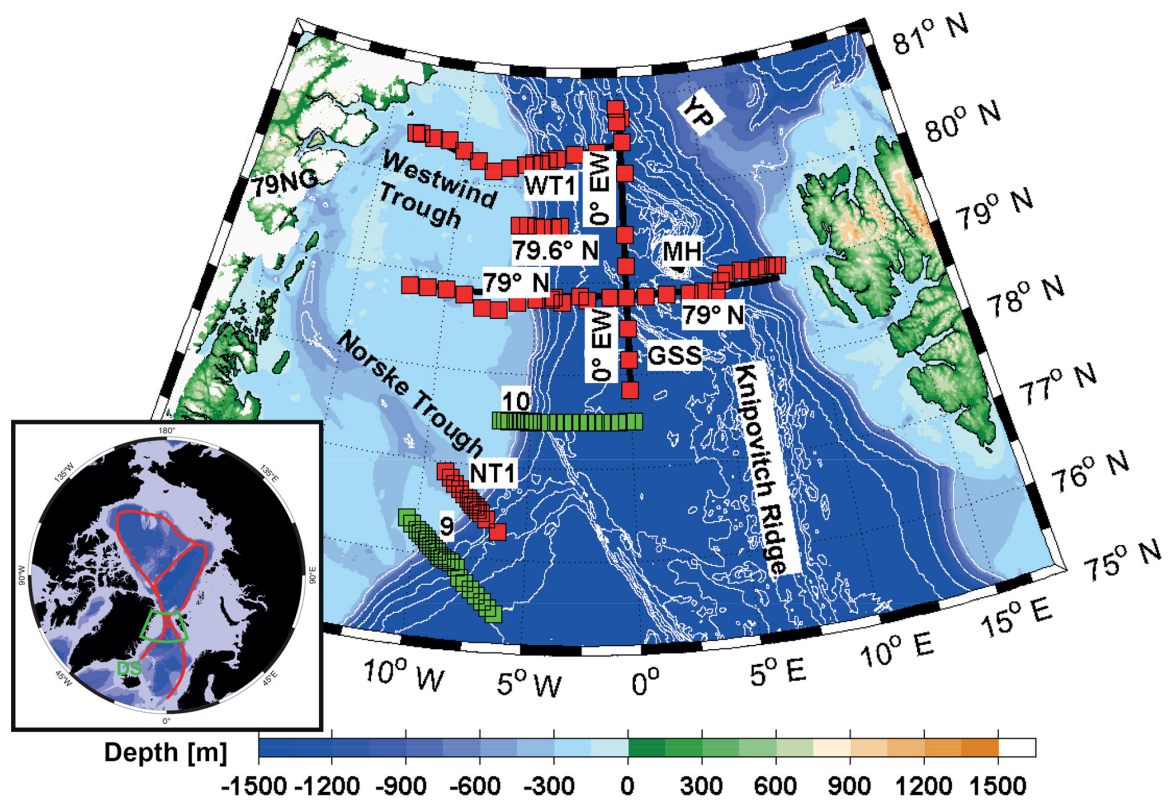

Figure 1. Map of the Fram Strait between east Greenland and Svalbard. The inset shows AW and AAW pathways in the Nordic Seas and Arctic Ocean and the location of Denmark Strait (DS). Station locations are shown as red squares, the interpolated sections as bold black lines. The section names of this study are WT1, 79.6 $6^{\circ} \mathrm{N}, \sim 79^{\circ} \mathrm{N}, \mathrm{NT} 1,0^{\circ} \mathrm{EW}$; also shown are sections 9 and 10 of Håvik et al. (2017) in green. The locations of the Norske and Westwind troughs, 79N Glacier (79NG), Yermak Plateau (YP), Knipovitch Ridge, Greenland-Spitsbergen Sill (GSS) and Molloy Hole (MH) are also shown. Bathymetry is from Schaffer et al. (2016).

Ocean (Aksenov et al., 2011), where it is transformed to Arctic Atlantic Water (AAW), which is fresher and colder than AW (Schauer et al., 1997; Rudels et al., 2005, 2012), before exiting the Arctic Ocean via the Fram Strait. The Arctic Ocean halocline separates the warm, salty intermediate waters of Atlantic origin from colder and fresher Polar Surface Water (PSW) at the surface (Rudels et al., 1996, 2005). Some of the AW is transformed into halocline water (e.g. Rudels et al., 2015). The WSC is a complex current with barotropic and baroclinic components, which splits into multiple branches (Quadfasel et al., 1987) and produces eddies (von Appen et al., 2016). At $79^{\circ} \mathrm{N}$ the WSC is made up of two branches, the shelf break branch and the offshore branch. The latter is stronger in winter than in summer and mostly baroclinic (Beszczynska-Möller et al., 2012). The zonal section across the Fram Strait most frequently occupied lies at $78^{\circ} 50^{\prime}-79^{\circ} \mathrm{N}$. An array of moorings along this line has made long-term observations possible. Both the mooring array and summer synoptic surveys of the WSC show a warming of the water column since the mid-1990s (Beszczynska-Möller et al., 2012; von Appen et al., 2015; Walczowski et al., 2017). Half to two-thirds of the AW flowing northward in the WSC at $79^{\circ} \mathrm{N}$ recirculates from the eastern boundary currents in the Fram Strait to the EGC in the west (Rudels, 1987; Manley, 1995; Marnela et al., 2013). North of $79^{\circ} \mathrm{N}$, the WSC splits into three branches: the Svalbard and Yermak branches (Perkin and Lewis, 1984) and a recirculating flow of AW (Gascard et al., 1995). The Svalbard branch was supposed to be the main flow of AW into the Arctic (Manley, 1995) though a pathway crossing the Yermak Plateau at the Yermak Pass (Gascard et al., 1995) was recently proposed as the main AW inflow to the Arctic Ocean (Koenig et al., 2017). The Yermak branch partly recirculates in the northern Fram Strait though there is no agreement in the literature on the exact amount and location (e.g. Aagaard et al., 1987; Manley, 1995; Schlichtholz and Houssais, 1999; Hattermann et al., 2016). The westward transport of AW from the WSC to the EGC was first proposed by Ryder (1895, p. 204) and has variously been described as a topographically steered branch of the Greenland Sea gyre in the southern part of the Fram Strait (following the Knipovitch Ridge and the Greenland-Spitsbergen Sill), as a cyclonic circulation around the Molloy Hole seen in models (Aksenov et al., 2010; Hattermann et al., 2016; Kawasaki and Hasumi, 2016; Wekerle et al., 2017a) and observations (Johannessen et al., 1987; Quadfasel et al., 1987), and as a field of topographically steered eddies, shed by the WSC, which merge with the EGC (Gascard et al., 1988, 1995). These eddies are also thought to be one mechanism that allows the AW to subduct underneath the sea ice and PSW advected from the Arctic Ocean southwards in the EGC (Hattermann et al., 2016). The wintertime peak in eddy kinetic energy (EKE) observed in the Fram Strait (von Appen et al., 2016) can be explained by the greater baroclinic and barotropic instability of the WSC in winter compared to summer (Teigen et al., 2010, 2011) due to decreased stratification of the upper water column 
(von Appen et al., 2016). An eddy-resolving grid is required in numerical models to reproduce the observed EKE levels (Hattermann et al., 2016; Wekerle et al., 2017a). This increases AW transport into the central Fram Strait and vertical transport of AW, i.e. subduction under sea ice and PSW. As described in Wekerle et al. (2017a), a correct eddy heat transport is also able to reduce the cold bias (a common bias in ice-ocean models (Ilicak et al., 2016) where modelled temperatures are lower than in observations) in the Finite Element Sea Ice-Ocean Model (FESOM) found in the central Fram Strait. The meridional extent of the recirculation is at present unclear. The location of the northern rim of the recirculation probably depends on the water mass tracked as well as the time of the measurements. Some observational studies locate the northern rim south of $81^{\circ} \mathrm{N}$ (Rudels et al., 2005). There is evidence from drifter data (Gascard et al., 1995), hydrographic surveys (Marnela et al., 2013), an inverse modelling study (Schlichtholz and Houssais, 1999) and a numerical ocean model (Kawasaki and Hasumi, 2016) that the recirculation in the Fram Strait may extend beyond $81^{\circ} \mathrm{N}$, possibly as far north as $82^{\circ} \mathrm{N}$. However, evidence from model studies in the Fram Strait is at present inconclusive as the northern limit of the recirculation, the strength of individual recirculation pathways and of the boundary currents varies between models (Maslowski et al., 2004; Aksenov et al., 2010; Hattermann et al., 2016; Ilicak et al., 2016; Wekerle et al., 2017a). This appears to be related to the resolution of the models and the bathymetry (Fieg et al., 2010). Observations able to determine the strength and location of the recirculation are therefore needed.

However, due to heavy sea-ice conditions observational studies in the central and western Fram Strait significantly north of $79^{\circ} \mathrm{N}$ are scarce. Thus, the northern AW recirculation and EGC remain undersampled and poorly understood. A study of the Arctic Ocean outflow along the northeast Greenland shelf break using data from 82 to $83^{\circ} \mathrm{N}$ (Falck et al., 2005) shows no recirculating AW there. South of $79^{\circ} \mathrm{N}$, the EGC is a current located offshore of the Greenland shelf break on the western side of the Fram Strait that transports recirculated AW and modified AAW below relatively fresh and cold PSW and sea ice from the Arctic (Aagaard and Coachman, 1968). Both recirculating AW and AAW lose contact with the atmosphere before reaching the northern Fram Strait. The different transit times through the Arctic Ocean ( $\sim 1$ year to tens of years: Karcher et al., 2003; Polyakov et al., 2011) compared to the recirculation in the Fram Strait (of the order of months for AW: Gascard et al., 1995; Hattermann et al., 2016) have also been inferred from the lower oxygen saturation of AAW compared to AW. Between $78^{\circ} \mathrm{N}$ and the Denmark Strait, the EGC consists of three branches: an inshore branch transporting fresh, cold water, a shelf break branch and a branch offshore of the shelf break believed to be a direct recirculation of AW from the western WSC branch (Woodgate et al., 1999; Nilsson et al., 2008; Håvik et al., 2017).
The aim of this study is to utilize the first synoptic dataset targeted at investigating the structure of the EGC and of the AW recirculation in the Fram Strait north of $79^{\circ} \mathrm{N}$. We will describe the hydrography (potential temperature, salinity, potential density) and the kinematics (absolute geostrophic velocity fields) along the path of Atlantic Water (AW) in the Fram Strait. We start with the inflow of AW and the WSC at $79^{\circ} \mathrm{N}$ in Sect. 3.1. Then, we turn to the central Fram Strait and the westward recirculation of AW crossing the prime meridian $\left(0^{\circ} \mathrm{EW}\right.$; Sect. 3.2$)$ before we follow the path of the southward flow along the east Greenland shelf from $\sim 80.3^{\circ} \mathrm{N}$ to $76.6^{\circ} \mathrm{N}$ in Sect. 3.3. We will examine the formation and transport of the EGC in Sect. 4.1 and take a look at shelf processes on the northeast Greenland shelf in Sect. 4.2. Throughout, we utilize an eddy-resolving numerical model (Wekerle et al., 2017a) to put the synoptic observations in a larger temporal and spatial context and to assess in which state of the highly variable flow regime the observations were taken. We close with conclusions from our findings in Sect. 5.

\section{Data and methods}

\subsection{CTD and ADCP data}

Data were collected between 18 July and 6 September 2016 during cruise PS100 of RV Polarstern. The data consist of 75 stations along five sections $\left(0^{\circ} \mathrm{EW} ; 79^{\circ} \mathrm{N}\right.$; WT1; $79.6^{\circ} \mathrm{N}$ and NT1; see Fig. 1). CTD casts (Kanzow et al., 2017a, b) were recorded with a dual duct Sea-Bird 911+ and averaged into $1 \mathrm{~m}$ bins (Kanzow, 2017). The conductivity and oxygen sensors were calibrated using water samples analysed on board (Kanzow, 2017) with an Optimare Precision salinometer and with a titration method, respectively. Upwardand downward-looking $300 \mathrm{kHz}$ RDI Workhorse acoustic Doppler current profilers (ADCPs) were used as a loweredADCP (LADCP) system (von Appen et al., 2017). A vesselmounted $150 \mathrm{kHz}$ RDI Ocean Surveyor ADCP (VMADCP) recorded ocean velocities along the cruise track (Kanzow and Witte, 2016). ADCP velocities were detided by subtracting the barotropic tidal component calculated from the Arctic Ocean Tidal Inverse Model (AOTIM-5; Padman and Erofeeva, 2004). The VMADCP and LADCP set-up and processing are described in detail in Kanzow (2017).

\subsection{Data processing}

For each section, station locations are projected onto the straight lines shown in Fig. 1 retaining their longitude (latitude in the case of $0^{\circ} \mathrm{EW}$ ). Bathymetry information from the ship's echosounder, the IBCAO V3 bathymetry (Jakobsson et al., 2012) and CTD altimeter station depths agreed to within tens of metres. Therefore, we use the linearly interpolated station depths to plot the bathymetry in the sections. In section WT1, the location of the shelf break is cor- 
rected using the echosounder bathymetry. The easternmost bathymetry at $79^{\circ} \mathrm{N}$ near the Svalbard shelf is corrected using IBCAO bathymetry of the Svalbard shelf break. In section $0^{\circ} \mathrm{EW}$ we use the bathymetry from IBCAO for the entire section and interpolated hydrographical values appearing below the defined seafloor are removed before plotting. For each CTD station the VMADCP velocity profiles are averaged whilst the ship was on station to attain a single profile. For each section the station data (CTD, LADCP and VMADCP) are interpolated onto a common grid with vertical resolution of $10 \mathrm{~m}$ and a horizontal resolution of half the mean station distance of the section (ranging from 5 to $20 \mathrm{~km}$ ) using a Laplacian-spline interpolation (Smith and Wessel, 1990). A standard tension of 5 ( $0=$ Laplacian interpolation, $\infty=$ spline interpolation) and a search radius of 10 grid points are used. Geostrophic shear is calculated from the gridded hydrography using thermal wind and is referenced to the $50-150 \mathrm{~m}$ averaged on-station VMADCP velocities (except for section NT1 where the 50-150 m LADCP data are used) to obtain absolute geostrophic velocities. For conceptual considerations, we additionally use a simple two-layer ocean approximation with a density difference of $0.3 \mathrm{~kg} \mathrm{~m}^{-3}$ to estimate baroclinic velocities from the slope of the $27.8 \mathrm{~kg} \mathrm{~m}^{-3}$ isopycnal. The position, width and core velocity of the shelf break EGC and WSC are defined following Håvik et al. (2017): the core velocity is the maximum of the $0-150 \mathrm{~m}$ mean velocity of the section. The boundaries of the EGC and WSC are defined as the locations where the $0-150 \mathrm{~m}$ mean velocity has decreased to $20 \%$ of the core value. This criterion is also used to define the boundaries of the EGC within which we calculate net transport. It has the advantage over using a fixed width or distance from the shelf break that it can account for a meandering current of variable width, as we expect to see in synoptic observations. To assess the errors due to the gridding process, the CTD and ADCP data are regridded increasing or decreasing parameters (a) tension, (b) search radius and (c) grid resolution individually by a factor of 2 . The relative absolute error of the absolute geostrophic velocity between the modified grid and the grid used in this study is determined. Velocity error estimates from parameters a and $\mathrm{b}$ are generally below $10 \%$, with some higher values occurring below $500 \mathrm{~m}$ outside of the EGC at $79.6^{\circ} \mathrm{N}$. Velocity errors from parameter $\mathrm{c}$ are mostly below $30 \%$, and higher values are found in areas of large and uneven station spacing. Note that a change in grid spacing of a factor of 2 is rather large and thus presents a maximum error estimate. The error of the VMADCP measurements is calculated as the median absolute deviation over the full sampling depth in time and space whilst on station and is $\sim 0.04 \mathrm{~m} \mathrm{~s}^{-1}$ with maximum values of $0.07 \mathrm{~m} \mathrm{~s}^{-1}$. The processing routine for LADCP velocities gives an error estimate dependant on depth for each cast (Thurnherr, 2010; Kanzow, 2017). The median error between 50 and $150 \mathrm{~m}$ depths at section NT1 is below $0.05 \mathrm{~m} \mathrm{~s}^{-1}$ for all except for the easternmost station where it is $0.1 \mathrm{~m} \mathrm{~s}^{-1}$. Transport error estimates combine er- rors from calculating the reference velocity from the ADCP measurements, errors introduced by the tidal model during detiding, errors in calculating the geostrophic velocity from the hydrography, the effect of station spacing and the ship's drift on station. Errors from the tidal model are mainly due to inaccuracies in the bathymetry used in the model. We try to minimize these errors by taking the tidal transport calculated by the model and then calculating the tidal velocity with a more exact bathymetry. The combined transport error was calculated following Sutherland (2008).

\subsection{Numerical model}

In this study we use the model output from the Finite Element Sea Ice-Ocean Model (FESOM) version 1.4 (Wang et al., 2014; Danilov et al., 2015). FESOM is an ocean-sea ice model which solves the hydrostatic primitive equations in the Boussinesq approximation. The sea-ice component applies the elastic-viscous-plastic rheology (Hunke and Dukowicz, 2001) and thermodynamics following Parkinson and Washington (1979). The finite element method is used to discretize the governing equations, applying unstructured triangular meshes in the horizontal and $z$ levels in the vertical. We use a global FESOM configuration that was optimized for the Fram Strait, applying a mesh resolution of $1 \mathrm{~km}$ in the area 75 to $82.5^{\circ} \mathrm{N}$ and -20 to $20^{\circ} \mathrm{E}$ and $4.5 \mathrm{~km}$ in the Nordic Seas and Arctic Ocean (Wekerle et al., 2017a). In comparison to the local Rossby radius of deformation (around 4-6 km in the Fram Strait; von Appen et al., 2016), this configuration can be considered as "eddy-resolving". The model bathymetry was taken from RTopo-2 (Schaffer et al., 2016). The model is forced with the atmospheric reanalysis data CORE.v2 (Large and Yeager, 2009), and interannual monthly river runoff is taken from Dai et al. (2009). The simulation covers the time period 2000-2009, and the daily model output was saved. Model runs do not go beyond 2009 since the forcing dataset does not include more recent years. Comparison with various observational data showed that the model generally performs very well in terms of circulation structure, eddy activity and hydrography (Wekerle et al., 2017a), which makes us confident that we can use it as a best-estimate realistic hindcast of the circulation and hydrography in the Fram Strait. However, there is a bias toward higher salinity in the AW layer of around 0.15 . This salinity bias can be traced back to the North Atlantic, and is a result of model deficiencies in correctly representing the pathways of the North Atlantic Current. The EKE is computed by decomposing velocities $u$ and $v$ into monthly means (denoted by a bar) and a deviating part (denoted by prime). The time-averaged EKE is then

$$
\overline{\mathrm{EKE}}=\frac{1}{2} \overline{\left(\left(u^{\prime}\right)^{2}+\left(v^{\prime}\right)^{2}\right)}=\frac{1}{2}\left(\overline{u^{2}}+\overline{v^{2}}-\bar{u}^{2}-\bar{v}^{2}\right) .
$$


Table 1. Water mass definitions after Rudels et al. (2005). Boundaries of potential temperature $\theta$ in ${ }^{\circ} \mathrm{C}$ and potential density $\sigma_{\theta}$ in $\mathrm{kg} \mathrm{m}{ }^{-3}$ are given; $\sigma_{\theta}$ is potential density referenced to the sea surface.

\begin{tabular}{lll}
\hline Water mass & Acronym & Definition \\
\hline $\begin{array}{l}\text { Polar Surface Water } \\
\text { warm Polar Surface Water }\end{array}$ & PSW & $\begin{array}{l}\sigma_{\theta} \leq 27.70, \theta \leq 0 \\
\sigma_{\theta} \leq 27.70, \theta>0\end{array}$ \\
\hline PSWw & AW & $\begin{array}{l}27.70<\sigma_{\theta} \leq 27.97, \theta>2 \\
\sigma_{\theta}<27.70, S>34.92\end{array}$ \\
\hline Arctantic Water & AAW & $27.70<\sigma_{\theta} \leq 29.97,0<\theta \leq 2$ \\
\hline $\begin{array}{l}\text { Deep Water } \\
\text { Denmark Strait Overflow Water Water }\end{array}$ & DW & $\begin{array}{l}\sigma_{\theta}>27.97 \\
\sigma_{\theta}>27.8, \text { depth }<800 \mathrm{~m}\end{array}$ \\
\hline
\end{tabular}

Table 2. Water mass endmember definitions for mixing calculations. Water mass acronyms as in Table $1, \theta$ is potential temperature.

\begin{tabular}{lrr}
\hline Water mass & Salinity & $\theta$ \\
\hline DW & 34.93 & -0.9 \\
AW & 35.1 & 4.1 \\
AAW & 34.8 & 0.8 \\
PSW & 34.17 & -1.8 \\
\hline
\end{tabular}

\subsection{Water mass definitions and calculations}

Water mass definitions (see Table 1) follow Rudels et al. (2005) except for very warm AW. Following Walczowski et al. (2017), we include water lighter than $27.7 \mathrm{~kg} \mathrm{~m}^{-3}$ with salinities above 34.92 in our definition of AW. This definition ensures that surface water in the WSC is defined as AW. Additionally we define Denmark Strait Overflow Water (DSOW) as water above $800 \mathrm{~m}$ depth which is denser than $27.8 \mathrm{~kg} \mathrm{~m}^{-3}$. The deep $\theta$ maximum is defined as the subsurface maximum in potential temperature, if this criterion is not sufficient it is defined as the depth of maximum salinity (Richter, 2017). Endmembers for mixing calculations are picked as the deepest water sampled (DW), the warmest subsurface $\theta$ peak found in the AW inflow region at $79^{\circ} \mathrm{N}(\mathrm{AW})$, the coldest clearly defined deep temperature maximum (AAW) and the coldest water sampled (PSW), and are given in Table 2. Since AW and/or AAW is always located between PSW and DW, and since DW and PSW are not observed to mix, we can describe our observations as either AW-AAW-PSW mixtures or as AW-AAW-DW mixtures. The resulting mixing triangles are shown in Fig. 2. Note that the relative contribution of AW and AAW in a water parcel that is mostly comprised of AW and AAW is not affected by this method. Error bars for the water-mass fractions are calculated by repeating the calculation 1000 times including random normally distributed uncertainties for the temperature and salinity of the endmembers with a standard deviation of $0.2^{\circ} \mathrm{C}$ and $0.04 \mathrm{PSU}$, respectively. Please note that the dis-

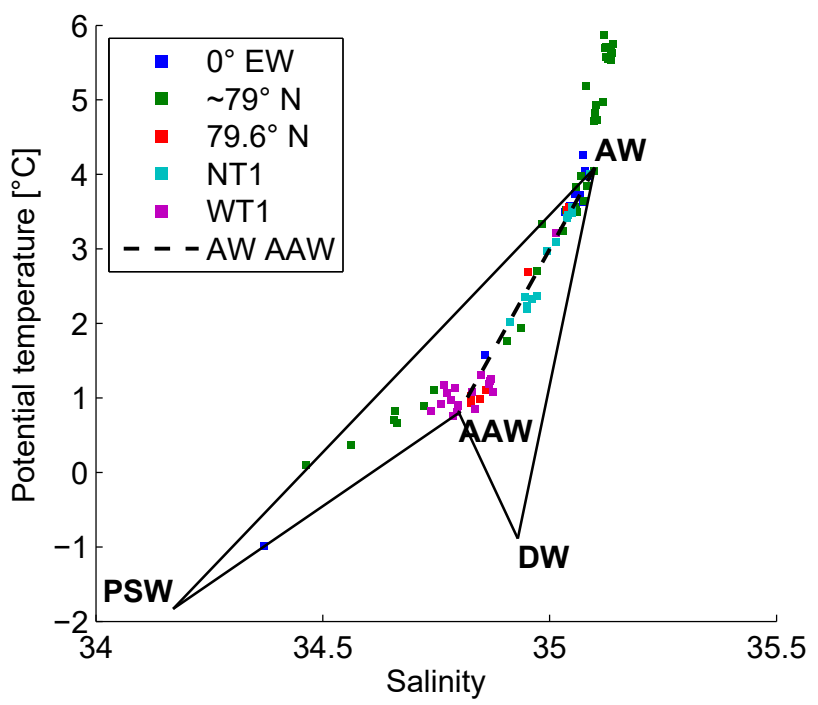

Figure 2. Mixing triangles of AW-AAW-PSW and AW-AAW-DW, abbreviations as in Table 1. Squares show the properties of the deep $\theta$ maximum at each station.

tribution of uncertainties naturally includes values outside of the \pm 1 standard deviation boundary. The reported uncertainties correspond to the standard deviation over all realizations of the water-mass calculation.

\section{Results}

We now present our results following the path of AW through the Fram Strait, from the inflow in the WSC via the recirculation in the central Fram Strait to the EGC. A particular emphasis is placed on the formation and evolution of the EGC.

\subsection{The AW inflow in the WSC}

The most striking feature of section $79^{\circ} \mathrm{N}$, as measured in summer 2016, is the highly dynamic velocity field (Fig. 3c). This can also be seen in daily averages from FESOM 


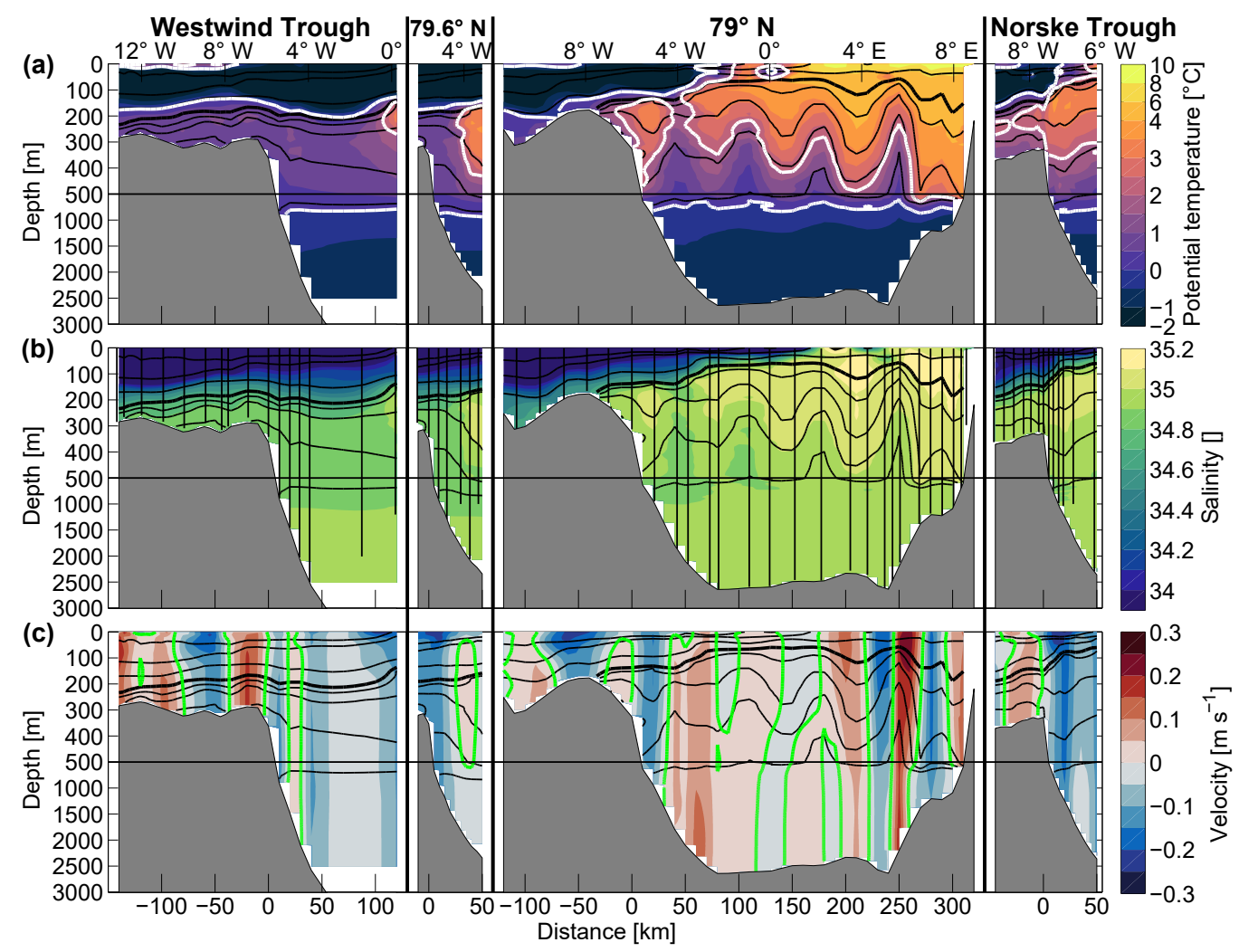

Figure 3. (a) Potential temperature, (b) salinity and (c) absolute geostrophic velocity for the sections crossing the east Greenland shelf break. Thin contours show potential density. The bold contour is the $27.8 \mathrm{~kg} \mathrm{~m}^{-3}$ isopycnal; above, the 26,27 and $27.6 \mathrm{~kg} \mathrm{~m}^{-3}$ isopycnals are shown, and below the density levels increase in $0.05 \mathrm{~kg} \mathrm{~m}^{-3}$ steps up to $28 \mathrm{~kg} \mathrm{~m}^{-3}$. Vertical black lines in (b) show station locations and depths. Please note the non-linear colour bars of salinity and temperature and that the y axis changes scale at $500 \mathrm{~m}$ depth (black line). The white contours in (a) show the 2 and $0^{\circ} \mathrm{C}$ isotherms. The green contours in (c) show the $0 \mathrm{~m} \mathrm{~s}^{-1}$ isotach. Positive velocities are northward, negative velocities are southward. Section distance is $0 \mathrm{~km}$ at the east Greenland shelf break. At $79^{\circ} \mathrm{N}$ there is a gap of 11 days between the stations east and west of $2^{\circ}$ E. Casts to the east were sampled within 6 days, casts to the west were sampled within 4 days.

(Movie S1b in the Supplement) and in the multi-year model average eddy kinetic energy at $79^{\circ} \mathrm{N}$ (Fig. 4c), which is significant across the Fram Strait east of $5^{\circ} \mathrm{W}$ and highest over the Svalbard shelf slope. This agrees with observations (von Appen et al., 2016). The velocity field may be comprised of eddies, which appear as strong velocity fluctuations paired around domes in the temperature and density fields (Fig. 3). While the precise horizontal structure of these cannot be resolved here, it matches that of the daily averages of the modelled velocity field (Movie S1 in the Supplement). It is clear that the flow is not smooth, i.e. unidirectional, in the WSC and EGC with near zero velocities as otherwise seen in longterm mean sections (e.g. Beszczynska-Möller et al., 2012). Separate from the eddies, we identify the northward velocities east of the $1000 \mathrm{~m}$ isobath on the Svalbard slope (Fig. 3c) as the WSC. This location agrees with the location of the WSC core both in long-term observations (BeszczynskaMöller et al., 2012) and FESOM output (Fig. 4b). The velocities in the eddies are instantaneously stronger than the WSC with peak velocities of -0.18 and $0.24 \mathrm{~m} \mathrm{~s}^{-1}$ (e.g. at
240 and $260 \mathrm{~km}$ in Fig. 3c). Whilst the $27.8 \mathrm{~kg} \mathrm{~m}^{-3}$ isopycnal (Fig. 3b) is almost flat in the deep Fram Strait (west of $2.5^{\circ} \mathrm{E}$ ), near the Svalbard slope it slopes downward toward the east with $0.64 \mathrm{~m} \mathrm{~km}^{-1}$. The downward sloping of isopycnals in the vicinity of the shelf break is a characteristic of baroclinic boundary currents, such as the WSC and EGC. The isopycnal slope is used to estimate the baroclinic velocity assuming a two-layer ocean as described in Sect. 2.2. This conceptual estimate gives a baroclinic velocity of $0.13 \mathrm{~m} \mathrm{~s}^{-1}$ in the WSC. Although only a rough estimate, this value is close to the absolute geostrophic velocity in the WSC of $0.11 \mathrm{~m} \mathrm{~s}^{-1}$ (Fig. 3c). We did not observe an offshore branch of the WSC, which is consistent with long-term measurements where the offshore branch is observed to be weakest or absent during summer months (Beszczynska-Möller et al., 2012; von Appen et al., 2016). Additionally, the presence of an offshore branch may be obscured by an eddy in our transect. The water column in the WSC is temperature stratified with a temperature maximum at the surface, while the minimum temperature is in the deep ocean (Fig. 3a, b). The sur- 
face temperatures of over $9^{\circ} \mathrm{C}$ on the west Spitsbergen slope are the highest water temperatures in the WSC near $79^{\circ} \mathrm{N}$ published so far and are likely due to the warming of the AW inflow to the Fram Strait (Beszczynska-Möller et al., 2012; Walczowski et al., 2017). The AW layer is over $500 \mathrm{~m}$ thick and is in contact with the atmosphere east of $5^{\circ} \mathrm{E}$ (Fig. 3a). Toward the west, the AW layer gets thinner and the depth of the temperature maximum increases. Although water warmer than $2{ }^{\circ} \mathrm{C}$ is found in the upper $50 \mathrm{~m}$ west of $5^{\circ} \mathrm{E}$, this water is too fresh to fall into the AW definition (Fig. 3a, b).

\subsection{The westward recirculation in the deep Fram Strait}

The synoptic section in the central Fram Strait shows a south to north transition along $0^{\circ} \mathrm{EW}$. At the southernmost station (near $78^{\circ} \mathrm{N}$ ) the water has an almost uniform salinity with warm AW close to the surface (the water in the upper tens of metres is too fresh to fall into the AW definition) and colder water at depth (Fig. 5a), similar to the stations sampled in the WSC along $79^{\circ} \mathrm{N}$ (Fig. 3a). With increasing latitude, the observed AW layer gets thinner, colder, fresher and is located deeper in the water column. This suggests that between the AW inflow at the surface in the WSC and the subsurface AW layer in the northern part of the central Fram Strait, AW subducts underneath colder and fresher PSW and sea ice. This was also simulated in the eddy-resolving model study of the Fram Strait by Hattermann et al. (2016) and it was hypothesized that baroclinic instability may achieve this subduction. The subduction of AW under PSW is also simulated in FESOM though this does not show a northward thinning of the AW layer (Fig. 5b). In the observations, the Arctic Ocean halocline, with cold, fresh PSW at the surface, is found in the upper $120 \mathrm{~m}$ of the water column north of $80^{\circ} \mathrm{N}$ below which Knee Water (KW, the saltiest water close to the freezing point line) is found. The properties of $\mathrm{KW}$ are indicative of the ice-ocean-atmosphere interaction in the Arctic Ocean (Moore and Wallace, 1988; Rudels et al., 2005) signalling that we observe water modified in the Arctic Ocean north of $80^{\circ} \mathrm{N}$. In addition to their maximum temperature (more or less than $2^{\circ} \mathrm{C}$ ) AW and AAW along $0^{\circ} \mathrm{EW}$ exhibit differences in oxygen saturation. Since AAW has transited through the Arctic Ocean, its oxygen saturation of typically $\sim 80 \%$ is significantly lower than the oxygen saturation of $\mathrm{AW}$ of typically $\sim 100 \%$.

AW is present somewhere in the water column at all stations along $0^{\circ} \mathrm{EW}$ except for the northernmost station at $80.8^{\circ} \mathrm{N}$ (Fig. 5a). This implies that we sampled either the northern rim of the recirculation as it was at the time of our measurements or that we sampled a passing AAW filament. We cannot decide which of the two explanations is true since no measurements farther north than $80.8^{\circ} \mathrm{N}$ were taken during the cruise. Examining the mean temperature in FESOM at $0^{\circ} \mathrm{EW}$ (Fig. 5b) shows average temperatures above $2{ }^{\circ} \mathrm{C}$ at $80.8^{\circ} \mathrm{N}$ in the central Fram Strait. This suggests that the northern rim of the recirculation in the model lies north- ward of this. Alternatively, the presence of warm water at this latitude in the model may be related to the presence of the Yermak branch flowing into the Arctic Ocean close to $0^{\circ} \mathrm{EW}$. However, this does not agree with the modelled average velocities in the AW layer (Figs. $5 \mathrm{~d}$ and $8 \mathrm{c}, \mathrm{d}$ ), which are southeastward north of $\sim 80^{\circ} \mathrm{N}$. AAW eddies with a temperature maximum below $2{ }^{\circ} \mathrm{C}$ are seen in the daily averages of the model run for 2009 (Movie S2 in the Supplement). Hence the model does not allow us to judge which of the two possible explanations is more likely. The synoptic observations made here do, however, show that the recirculation in the Fram Strait can reach as far north as $80.7^{\circ}$ N. A repeat synoptic survey along $0^{\circ} \mathrm{EW}$, with a higher resolution than in the present study, extending beyond $81^{\circ} \mathrm{N}$, supported by a mooring array, could provide a more definite picture of the northern limit of the Fram Strait recirculation and its meridional and temporal structure. This could then be used to verify numerical models. In the central Fram Strait along $0^{\circ} \mathrm{EW}$ (Fig. 5c), the coarse resolution section depicts an absolute geostrophic velocity field which switches between broad sectors of weak eastward $\left(\sim 78^{\circ} \mathrm{N}\right.$ and $\left.\sim 79.5^{\circ} \mathrm{N}\right)$ and westward velocity $\left(\sim 78.5\right.$ to $\sim 79^{\circ} \mathrm{N}$ and around 80 to $80.5^{\circ} \mathrm{N}$ ); Velocities reach $\pm 0.12 \mathrm{~m} \mathrm{~s}^{-1}$. The velocity field appears mostly barotropic but the station spacing of $\sim 40 \mathrm{~km}$ is not able to resolve the flow structure. We expect the velocity field, at least in the vicinity of $79^{\circ} \mathrm{N}$, to be similar to the velocity field shown in Fig. $3 \mathrm{c}$ at $79^{\circ} \mathrm{N}$ and $0^{\circ} \mathrm{EW}$. This is supported by the modelled EKE (Fig. 5f), which is highest close to $79^{\circ} \mathrm{N}$ and the daily velocity field (Movie S2 in the Supplement), which shows much narrower velocity structures. Further, the section at $0^{\circ} \mathrm{EW}$ is less synoptic than the other sections presented in this study due to large time gaps between some stations (see caption of Fig. 5). Note that the water-mass properties are not affected by the coarse temporal and spatial resolution. Previous studies have reported eastward transport north of $79^{\circ} 30^{\prime} \mathrm{N}$ at $0^{\circ} \mathrm{EW}$ (Marnela et al., 2013) variously related to the Molloy Hole (e.g. Hattermann et al., 2016). This is seen in the observations though not in the model average. The model study by Hattermann et al. (2016) described two branches of westward recirculation through the Fram Strait, at $78.5^{\circ} \mathrm{N}$ and at $80^{\circ} \mathrm{N}$. This agrees well with our synoptic section at $0^{\circ} \mathrm{EW}$, both with the velocity field and, more conclusively, with the location of two salinity fronts (Fig. 5b, c). FESOM also shows two recirculation branches, which merge at $0^{\circ} \mathrm{EW}$ (Fig. 8c, d). Long-term averages of model output suggest that the mean current through $0^{\circ} \mathrm{EW}$ is southwestward (Hattermann et al., 2016; Kawasaki and Hasumi, 2016; Wekerle et al., 2017a, and Fig. 5d in this study) and daily averages of the velocity field from FESOM show eddies advected southwestward (Movie S2 in the Supplement). 


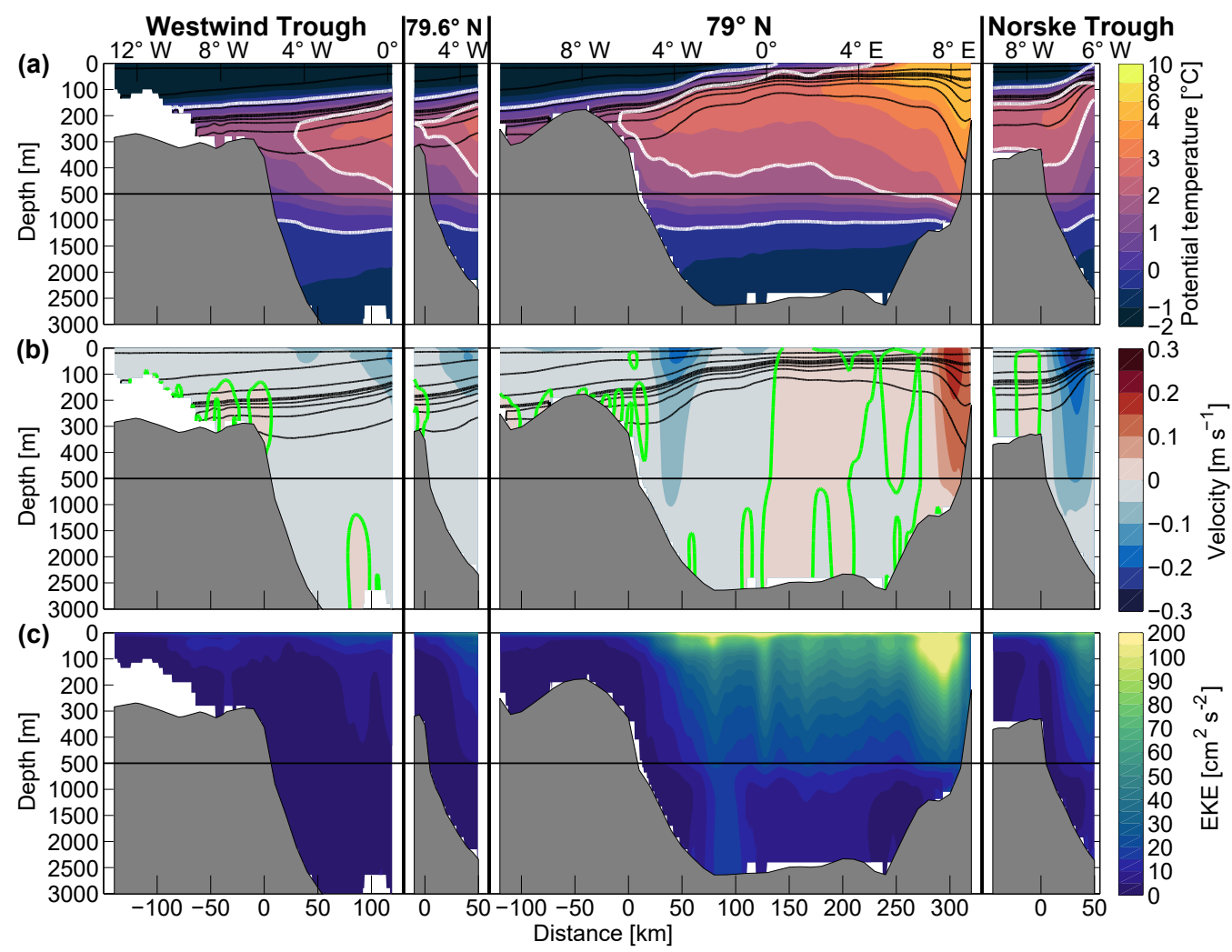

Figure 4. Eight year July/August/September average FESOM realizations of the sections crossing the east Greenland shelf break for (a) Potential temperature (as in Fig. 3a), (b) velocity (as in Fig. 3c) and (c) EKE.

\subsection{The evolution of the EGC from the northern Fram Strait to the Greenland Sea}

In the synoptic section roughly perpendicular to the east Greenland shelf break at $\sim 80.3^{\circ} \mathrm{N}$ (Section WT1), AW is only found in the central Fram Strait near $0^{\circ} \mathrm{EW}$, some $130 \mathrm{~km}$ east of the Greenland shelf break (Fig. 3a). This is closer to the Svalbard shelf break than the Greenland shelf break. The deep $\theta$ maxima sampled west of $0^{\circ} \mathrm{EW}$ at WT1 have temperatures around $1{ }^{\circ} \mathrm{C}$, well below the temperature of AW, and salinities between 34.8 and 34.9 (Fig. 6a). This agrees with deep $\theta$ maxima from stations sampled between $82-83^{\circ} \mathrm{N}$ and $10-5^{\circ} \mathrm{W}$ in 2004 (Rudels et al., 2012), which, together with the transport measured there (Marnela et al., 2008), indicates that the AAW sampled at WT1 may be advected from the northwest along the east Greenland shelf break. Thus, the Arctic Ocean outflow of AAW sampled at $80.3^{\circ} \mathrm{N}$ is uninfluenced by directly recirculating AW west of $0^{\circ}$ EW. Salinity (Fig. 3b) increases strongly in the halocline over the upper $150 \mathrm{~m}$. The density field (thin contour lines in Fig. 3b) closely follows the salinity field. At the mouth of the Westwind Trough the temperature of the deep $\theta$ maximum is $\sim 0.8^{\circ} \mathrm{C}$. Outside of the trough, two regions of southward flow were sampled (Fig. 3c). The local velocity maximum between 0 and $20 \mathrm{~km}$ offshore of the shelf break with relatively weak core velocities of $-0.09 \mathrm{~m} \mathrm{~s}^{-1}$ is at a cross-shelf-break distance where the shelf break EGC is found farther south. The broad southward flow between $5^{\circ} \mathrm{W}$ and $0^{\circ} \mathrm{EW}$ ( 30 and $120 \mathrm{~km}$ ), identified as the Arctic Ocean outflow, is also visible in the modelled velocity field (Fig. 4b). Both bands of southward flow are highly barotropic and modelled EKE is negligible at WT1 (Fig. 4c). In the Arctic Ocean outflow, at $\sim 80.3^{\circ} \mathrm{N}$ (section WT1), the slope of the $27.8 \mathrm{~kg} \mathrm{~m}^{-3}$ isopycnal between $0^{\circ} \mathrm{EW}$ and the shelf break (Fig. 3b) is very weak $\left(0.25 \mathrm{~m} \mathrm{~km}^{-1}\right.$, corresponding to a baroclinic velocity of only $0.05 \mathrm{~m} \mathrm{~s}^{-1}$ ). In this respect the southward flow at WT1 is different from the welldefined baroclinic boundary current structure of the EGC farther south commonly described in the literature. Likewise, the 2001-2009 FESOM model mean shows weak isopycnal slopes (Fig. 4). Thus we hypothesize that the southward flow at WT1 may not be a boundary current tied to the shelf break. In the 8-year model average, the AW reaches much closer to the shelf break at $80.3^{\circ} \mathrm{N}$ than in the synoptic section (Fig. 4a) and actually reaches the shelf break during $20 \%$ of the year, though it does not propagate into the Westwind Trough. In the FESOM configuration used here (Wekerle et al., 2017a), runoff is taken from the interannual dataset of Dai et al. (2009), which does not take into account subglacial and submarine melting of the Greenland ice sheet. This, how- 

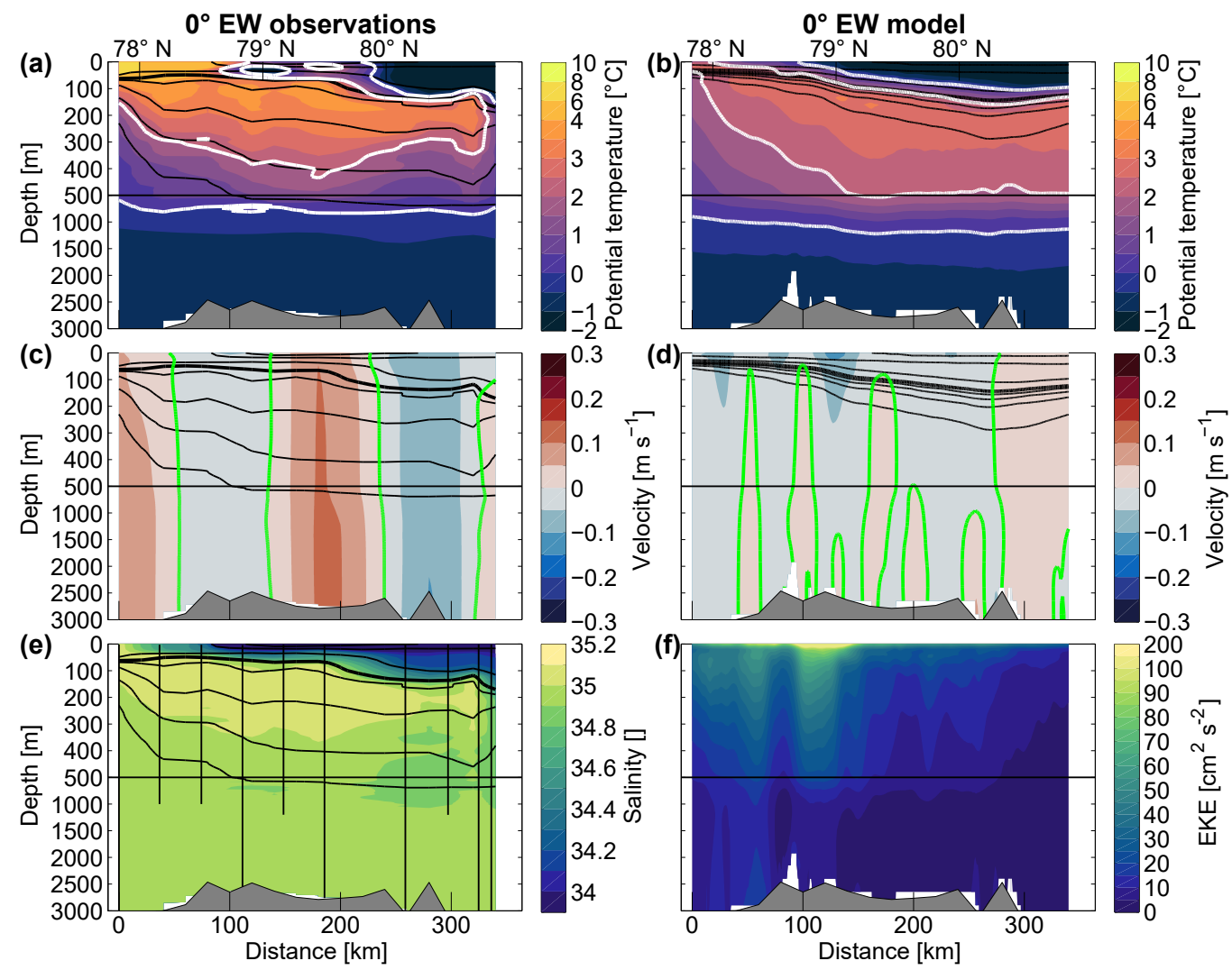

Figure 5. Left column: (a) Potential temperature, (c) absolute geostrophic velocity and (e) salinity as in Fig. 3 but for the section at $0^{\circ}$ EW. The southernmost station was sampled last, 24 days after its northern neighbour. The next two stations were sampled 13 days after their northern neighbour. All remaining stations were occupied within 4 days. Right column: eight year July/August/September average FESOM realizations of (b) potential temperature, (d) velocity and (f) EKE as in Fig. 4 but for the section at $0^{\circ}$ EW. Positive velocities are eastward, negative velocities are westward.

ever, may be crucial to represent the northeast Greenland shelf circulation correctly. A different freshwater input from Greenland would likely have effects both on the circulation in the troughs and on water-mass transport and transformation in the southward flow along the shelf break. It may thus impact the distance from the shelf break at which AW is found in the model. From comparison with the sparse observations available (this study, a synoptic section in Rudels et al., 2005, and the climatology in Schaffer et al., 2017) we are inclined to trust the density and velocity field in FESOM in the northern Fram Strait, but are more cautious about the distribution of AW. Thus, correctly modelled currents may advect the wrong water mass in the model, specifically AW may be simulated too far in the west.

Just $50 \mathrm{~km}$ farther to the south, at $79.6^{\circ} \mathrm{N}$, AW is found merely $30 \mathrm{~km}$ offshore of the shelf break in a core between 150 and $450 \mathrm{~m}$ of depth (Fig. 3a). The $27.8 \mathrm{~kg} \mathrm{~m}^{-3}$ isopycnal has a downward slope of $0.5 \mathrm{~m} \mathrm{~km}^{-1}$ toward the shelf break (this corresponds to a baroclinic velocity of $0.1 \mathrm{~m} \mathrm{~s}^{-1}$ ), which has a greater similarity to the EGC structure farther south (Håvik et al., 2017) than the WT1 section. The offshore divergence of the isopycnals may be caused by AW intruding below, into and/or above the AAW layer at depth. The spreading apart of the isopycnals in the ambient AAW by intruding AW is likely a generic process (i.e. not just present in this synoptic section), taking place whenever AW meets AAW at depth with a distinct and strong horizontal gradient in stratification. Intruding AW at depth has lower stratification consistent with the strong atmospheric cooling experienced relatively recently by the AW in the Nordic Seas boundary current loop. Some interleaving is present in the CTD profiles at the transition between AW and AAW $30 \mathrm{~km}$ from the shelf break (orange profile in Fig. 6b). Largely barotropic southward velocities $\left(\sim 0.16 \mathrm{~m} \mathrm{~s}^{-1}\right.$, Fig. $\left.3 \mathrm{c}\right)$ are found just offshore of the shelf break. While the isopycnal slope at $79.6^{\circ} \mathrm{N}$ in the synoptic section and the 8-year model average (Fig. 4) are similar to the familiar boundary current structure of the EGC farther south, the core of the modelled southward velocities lies farther from the shelf break than in our synoptic section. The modelled daily average velocities (Movie S1 in the Supplement) suggest that the main cause of high southward velocities near the shelf break are eddies passing through 


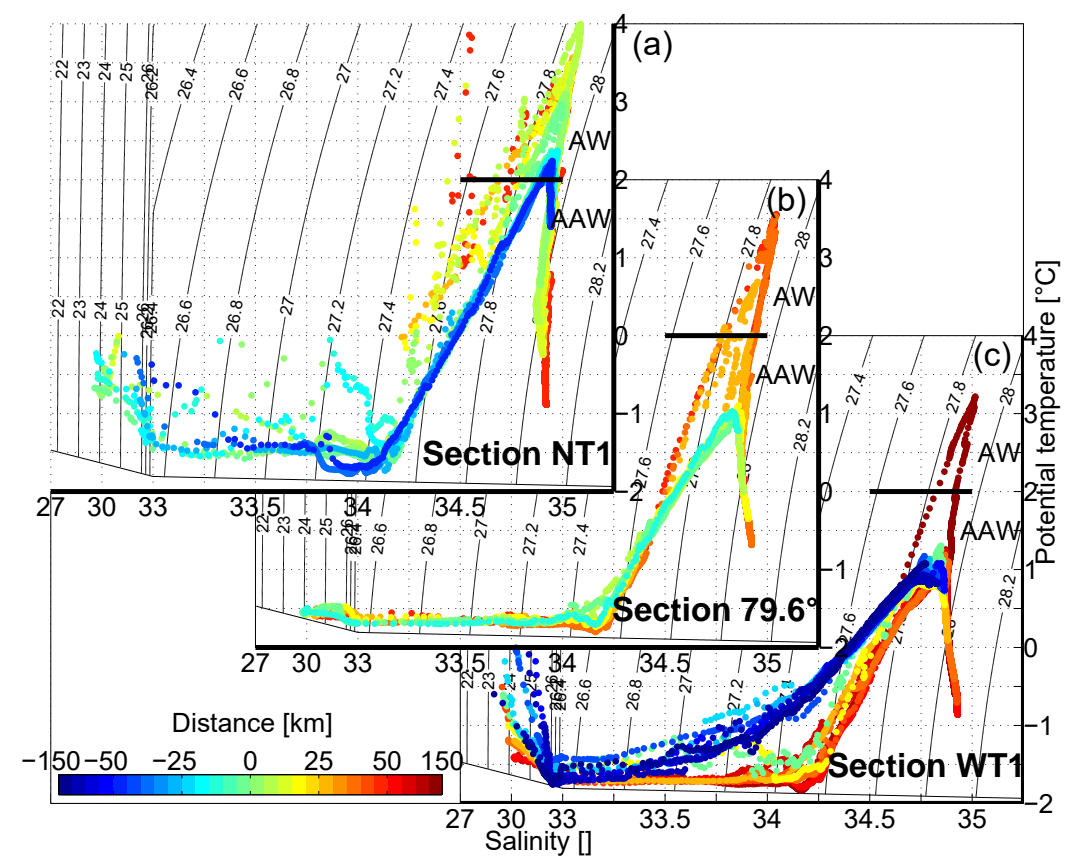

Figure 6. Potential temperature-salinity diagrams for three sections crossing the east Greenland shelf break (WT1, 79.6 $6^{\circ}$ and NT1). Individual casts are colour coded depending on their distance to the east Greenland shelf break (positive $=$ offshore). Please note that the $\mathrm{x}$ axis changes scale at 33 . The solid black line shows the water-mass boundary between AW and AAW (see Table 1).

$79.6^{\circ} \mathrm{N}$. The mean modelled EKE and velocity (Fig. 4b, c) show higher values at the same distance from the shelf break supporting this interpretation. This means that our observation may either have resolved the southward flowing rim of an eddy or we sampled $79.6^{\circ} \mathrm{N}$ at a time when the EGC was a boundary current and close to the shelf break. The latter is supported by the fact that in the model the southward flow at $79.6^{\circ} \mathrm{N}$ lies closer to the shelf break in summer than in winter (Fig. 8). Conversely, the upward sloping isopycnals seen below $200 \mathrm{~m}$ suggest the presence of an AW eddy in the synoptic section.

Another $80 \mathrm{~km}$ farther to the south, at $79^{\circ} \mathrm{N}, \mathrm{AW}$ is found at $\sim 200 \mathrm{~m}$ depth at the east Greenland shelf break though no AW is found on the east Greenland shelf (Fig. 3a). The $27.9 \mathrm{~kg} \mathrm{~m}^{-3}$ isopycnal undulates strongly, following the temperature field. Whilst the isopycnals $<27.8 \mathrm{~kg} \mathrm{~m}^{-3}$ are almost flat above $100 \mathrm{~m}$ depth in the deep Fram Strait (between $2.5^{\circ} \mathrm{W}$ and $2.5^{\circ} \mathrm{E}$ ) they deepen toward the west. The downward sloping isopycnals (a slope of $0.75 \mathrm{~m} \mathrm{~km}^{-1}$ toward the shelf break for the $27.8 \mathrm{~kg} \mathrm{~m}^{-3}$ isopycnal corresponding to a baroclinic velocity of $0.15 \mathrm{~m} \mathrm{~s}^{-1}$ ) are located at a distance from the shelf break at which the shelf break EGC is found in mooring observations (e.g. Beszczynska-Möller et al., 2012) and our model average (Fig. 4b), and coincide with southward absolute geostrophic velocities (Fig. 3c). Thus this section shows the familiar structure of the EGC as a baroclinic boundary current.
At $79^{\circ} \mathrm{N}$ there are two cores of southward velocities (Fig. 3c). We identify the core just offshore of the shelf break centred around $5^{\circ} \mathrm{W}(20 \mathrm{~km})$ and reaching $-0.15 \mathrm{~m} \mathrm{~s}^{-1}$ as the shelf break EGC. The modelled average temperature and velocity field are naturally smoother than the synoptic section but show the same general structure with AW subducting westward below PSW (Fig. 4a). The EKE at $79^{\circ} \mathrm{N}$ is much higher than at the sections sampled to the north and south of this and has a peak where the EGC is found. This high variability can also be seen in the daily averages of the velocity fields (Movie S1 in the Supplement).

At the mouth of the Norske Trough $\left(76.6^{\circ} \mathrm{N}\right.$, i.e. another $270 \mathrm{~km}$ farther to the south along the shelf break), AW is found in a broad core between 100 and $350 \mathrm{~m}$ depth at and offshore of the shelf break (Fig. 3a). Inside the trough, a thin layer of AW is found between 200 and $250 \mathrm{~m}$, i.e. above $320 \mathrm{~m}$, which is the depth of the shallowest sill between the shelf break and the inner shelf near the NEGIS glaciers (Schaffer et al., 2017). The model also shows an AW layer within the Norske Trough, both in the 8-year average (Fig. 4a) and in the daily averages for 2009 (Movie S1 in the Supplement). Thus, AW is able to propagate through the Norske Trough to the termini of the NEGIS glaciers. However, the modelled AW layer is thicker inside the Norske Trough than in the observations and thins eastward. Since this also does not agree with the temperature observations in the Norske Trough reported in Schaffer et al. (2017), we again conclude that the model transports too much AW too 
far eastward. The temperature of the synoptic deep $\theta$ maximum decreases from east to west and its depth increases (Fig. 6c). Observed salinities (Fig. 3b) are lowest at the surface and on the shelf. The density field largely follows the salinity field and isopycnals deepen toward the west (Fig. 3b). The $27.8 \mathrm{~kg} \mathrm{~m}^{-3}$ isopycnal has a downward slope of $1.66 \mathrm{~m} \mathrm{~km}^{-1}$ toward the west which corresponds to a baroclinic velocity of $0.33 \mathrm{~m} \mathrm{~s}^{-1}$. Absolute geostrophic velocities on the shelf are northeastward, whereas the shelf break EGC flows southwestward on the slope, both in the observations and in the model, with high velocities $\left(0.15-0.3 \mathrm{~m} \mathrm{~s}^{-1}\right)$ throughout the water column (Fig. 3c). The core of the measured flow is located around $7^{\circ} \mathrm{W}$ (at $20 \mathrm{~km}$ ) and reaches $-0.26 \mathrm{~m} \mathrm{~s}^{-1}$. The EGC has a width of approximately $40 \mathrm{~km}$ and the observations show some surface intensification in its western half, whereas the eastern part is more barotropic. The location and width of the shelf break EGC at NT1 agree well with section 10 from Håvik et al. (2017), which is located $\sim 30 \mathrm{~km}$ to the north of section NT1.

\section{Discussion}

In the following we will examine the evolution of the Arctic Ocean outflow to the EGC from north to south. The change in dynamics is addressed by examining the baroclinic and barotropic components of the southward flow. We will then discuss the transport along the shelf break, examining the different water masses (e.g. DSOW transport) and compare this with observations of the EGC farther south. Finally we will draw inferences from our results about the circulation on the northeast Greenland shelf.

\subsection{Formation of and transport in the EGC}

Both the observations and the model indicate that the recirculating AW first gets close to the east Greenland shelf break between the mouth of the Westwind Trough at 80.3 and $79.6^{\circ}$ N. From our observations (Fig. 3) and the modelled velocity field of the AW layer in the Fram Strait (Fig. 8c, d) we argue that this is likely to take place closer to $79.6^{\circ} \mathrm{N}$ than to WT1. The three sections crossing the EGC downstream of WT1 show different stages of water-mass transformation in the deep temperature maximum (Fig. 6): from AAW and AW located horizontally next to another at $79.6^{\circ} \mathrm{N}$ to successively greater mixing between the two until the deep temperature maximum is warmer than $2{ }^{\circ} \mathrm{C}$ (and thus falls into the AW definition) at all stations sampled in section NT1. Successively more AW gets entrained into the core of the EGC from north to south, with the contribution of the AW endmember increasing from only $19 \pm 8 \%$ at WT1 to $80 \pm 3 \%$ at NT1 (Fig. 7c). This can also be seen in the north to south increase in temperature, salinity and oxygen concentration, and the decrease in the depth and density of the deep temperature maximum within the core of the southward flow (Fig. 7a, b). The EGC at $79^{\circ} \mathrm{N}$ stands out as having the high- est spread of values for all examined properties; a result of the strong ongoing stirring between the AAW transported in the EGC and recirculating AW from the east, mixing then takes some more time to homogenize the water properties. This high variability in water-mass properties at $79^{\circ} \mathrm{N}$ is not merely synoptic, the modelled 8-year average EKE at $79^{\circ} \mathrm{N}$ (Fig. 4c) is significantly higher than at the sections crossing the east Greenland shelf break to the north and south. Modelled EKE is negligible at WT1; to the south of WT1, values increase and higher EKE values are found closer to the shelf break. South of $79^{\circ} \mathrm{N}$ the EKE decreases again though the EKE maximum at NT1 is found closer to the shelf break than at $79^{\circ} \mathrm{N}$, consistent with a "funnelling" of the southward flow. The high EKE values at $79^{\circ} \mathrm{N}$ would argue that the bulk of the eddy field of the recirculation crosses the Fram Strait there. This is also seen in the model realization of section $0^{\circ} \mathrm{EW}$ where the highest westward velocities coincide with the highest EKE values at $\sim 79^{\circ} \mathrm{N}$ (Fig. 5d, f). The transport of the southward flow along the shelf break varies between $-0.9 \pm 0.75 \mathrm{~Sv}$ at WT1 and $-4.0 \pm 0.75 \mathrm{~Sv}$ at NT1 and generally increases downstream (Fig. 7d). The exception is $79^{\circ} \mathrm{N}$ where the shelf break EGC transports only $1.1 \pm 1.2 \mathrm{~Sv}$, which is over $1.5 \mathrm{~Sv}$ less than at $79.6^{\circ} \mathrm{N}$. (Since the section at $79.6^{\circ} \mathrm{N}$ did not sample the western edge of the southward flow at $79.6^{\circ} \mathrm{N}$, transport through that section presents a minimum estimate.) The mean southward core velocity increases from $-0.08 \mathrm{~m} \mathrm{~s}^{-1}$ at WT1 to $-0.26 \mathrm{~m} \mathrm{~s}^{-1}$ at NT1, again with section $79^{\circ} \mathrm{N}$ an exception (Fig. 7d). We have higher absolute errors at sections where a narrow current is sampled with relatively few stations. The relative error is especially high at $79^{\circ} \mathrm{N}$ where the transport is low due to the highly variable synoptic flow field with flow reversals on small spatial scales. This also means that a closer station spacing would not necessarily make the flow field more interpretable and may lead to an even lower transport estimate. The transport through $79^{\circ} \mathrm{N}$ is low when compared with previous estimates of southward transport through $79^{\circ} \mathrm{N}$ (e.g. Schlichtholz and Houssais, 1999; Fahrbach et al., 2001; de Steur et al., 2009, 2014). Between $79^{\circ} \mathrm{N}$ and $78^{\circ} 50^{\prime} \mathrm{N}$ the summer mean EGC transport increases by $\sim 2 \mathrm{~Sv}$ (de Steur et al., 2014) implying that a recirculation of this magnitude joins the EGC between these two sections (this transport estimate includes, but is not restricted to, AW). In winter, the transport increases by an additional $\sim 3 \mathrm{~Sv}$ between the two latitudes, likely due to an intensification of the Greenland Sea gyre (de Steur et al., 2014). Even the summer increase of $2 \mathrm{~Sv}$ is higher than the increase in our synoptic summer transport between $79.6^{\circ} \mathrm{N}$ and section NT1 (Fig. 7d). A more inclusive definition of the EGC, calculating transport at $79^{\circ} \mathrm{N}$ between $0^{\circ} \mathrm{EW}$ and $6^{\circ} \mathrm{W}$ (the latitudes used in de Steur et al., 2009, 2014) results in net northward transport in the synoptic section. Of course, de Steur et al. $(2009,2014)$ report multi-year monthly means whereas our study is synoptic. It also has to be kept in mind that the station spacing of the moorings is wider than our station spacing and thus interpolation between moorings 


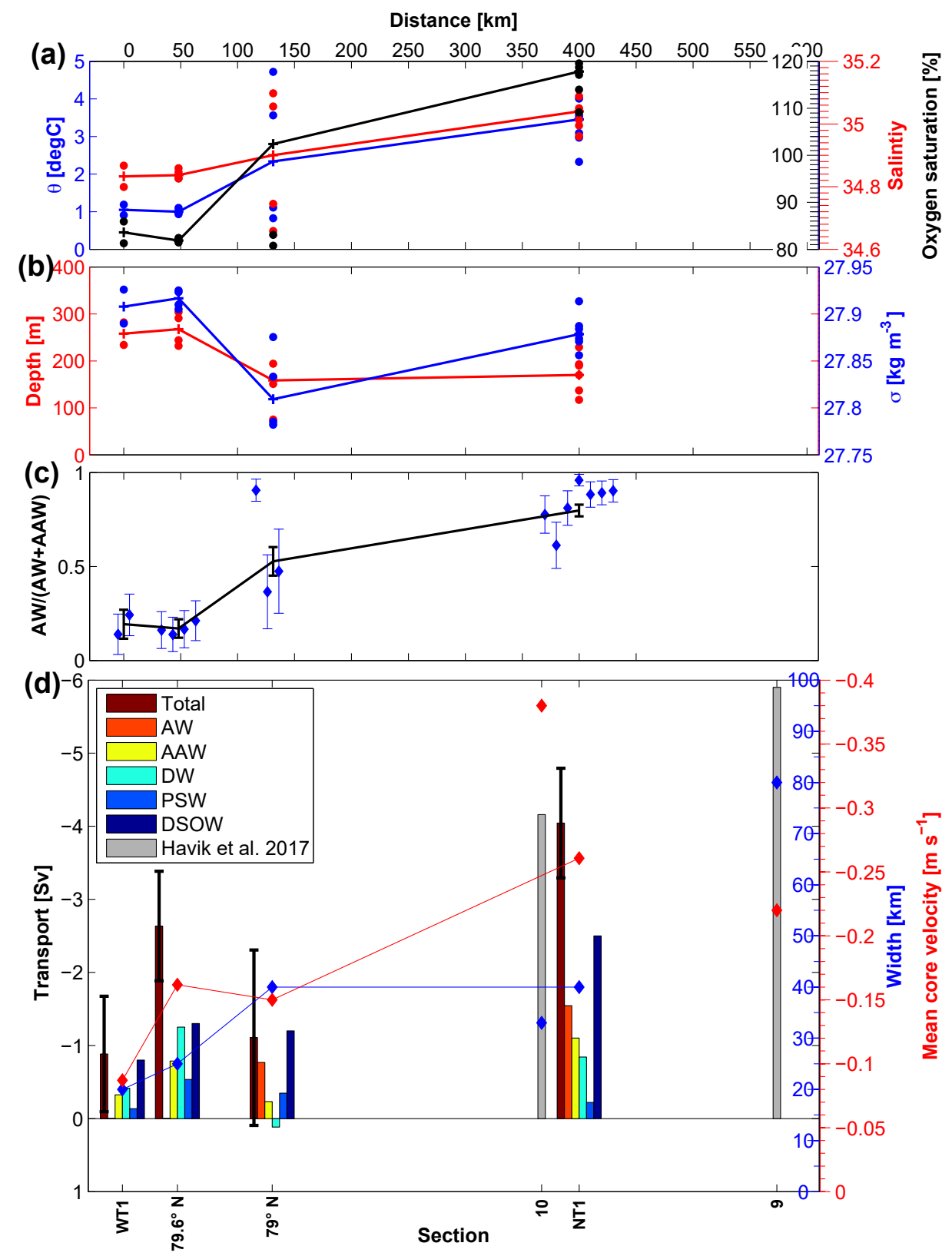

Figure 7. Properties of the $\theta$ maximum in the shelf break EGC from north to south: (a) potential temperature, salinity and oxygen saturation; (b) depth and potential density; and (c) AW fraction as a function of AW + AAW for individual stations (blue, horizontally offset for clarity) and for the average at each section (black). Error bars show the \pm 1 standard deviation. Transport, velocity and width of the shelf break EGC in the Fram Strait as defined in Håvik et al. (2017) are shown in (d). Southward transport is negative. Water-mass definitions are as in Table 1. Downstream distance (in km) is $0 \mathrm{~km}$ at WT1 and follows the east Greenland shelf break southward. Values for sections 9 and 10 of Håvik et al. (2017) are taken from their paper.

may remove much of the small-scale variability that reduces transport in the synoptic section at $79^{\circ} \mathrm{N}$. The majority of the synoptic transport measured at $79^{\circ} \mathrm{N}$ is synoptic AW transport. The synoptic transport of AAW, PSW and DW at $79^{\circ} \mathrm{N}$ is lower than at $79.6^{\circ} \mathrm{N}$. This signal may be due to temporal variability or due to a change in pathway of these wa- ter masses. AAW and PSW are found on the shelf at $79^{\circ} \mathrm{N}$ where a surface-intensified jet, which appears to be similar to the PSW Jet of Håvik et al. (2017), has a southward transport of $1.1 \mathrm{~Sv}$ (Fig. 3c).

Most, $91 \pm 5 \%$, of the AW and the AAW have a density $>27.8 \mathrm{~kg} \mathrm{~m}^{-3}$, which is the density definition of Denmark 

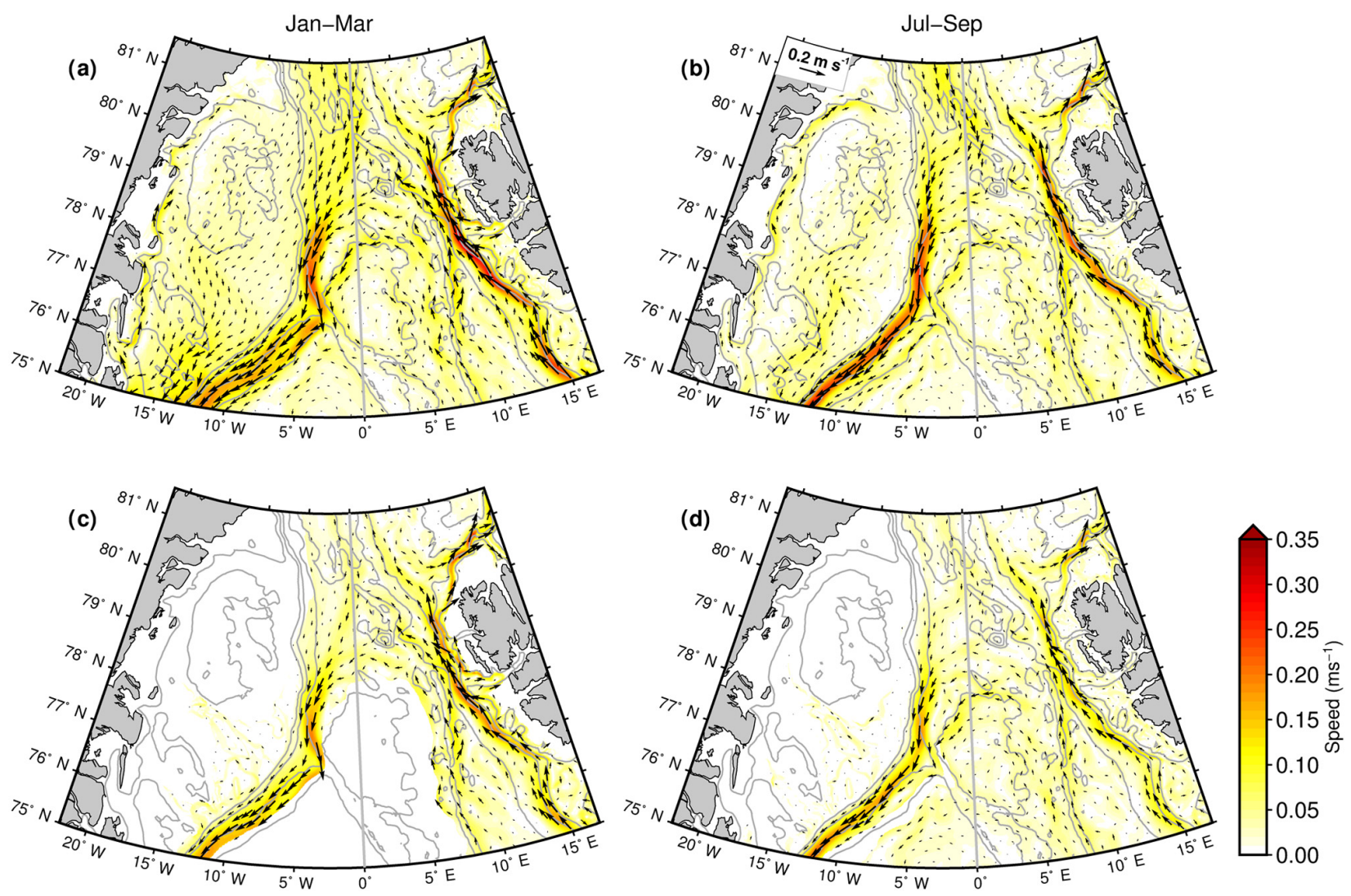

Figure 8. (a, b) simulated velocity at $75 \mathrm{~m}$ depth and (c, d) depth-averaged simulated velocity in the AW layer (water warmer than $2{ }^{\circ} \mathrm{C}$ ) for the time periods $(\mathbf{a}, \mathbf{c})$ January-March and $(\mathbf{b}, \mathbf{d})$ July-September from FESOM. Thin grey lines are bathymetry, black arrows show current speed and direction, and the coloured shading shows the speed.

Strait Overflow Water (DSOW, Fig. 7d). Transport of DSOW increases from $-0.8 \mathrm{~Sv}$ at $\mathrm{WT} 1\left(80.3^{\circ} \mathrm{N}\right)$ to $-2.5 \mathrm{~Sv}$ at $\mathrm{NT} 1$ $\left(76.5^{\circ} \mathrm{N}\right)$. This may be explained by the gradual formation of the EGC as a baroclinic boundary current and the recirculating AW joining the current. We use a lower boundary of $800 \mathrm{~m}$ in our definition because Harden et al. (2016) demonstrated that north of the Denmark Strait aspiration across the strait's sill takes place down to $\sim 800 \mathrm{~m}$. If the deep $0{ }^{\circ} \mathrm{C}$ isotherm is used as a lower boundary (as done in Håvik et al., 2017) then our transport estimates increase by $\sim-0.1 \mathrm{~Sv}$ at each section. Remarkably, our transport estimate for DSOW at NT1 of $-2.5 \mathrm{~Sv}$ agrees well with the $-2.8 \pm 0.7 \mathrm{~Sv}$ average of the DSOW transport from 10 synoptic sections between 78 and $68^{\circ} \mathrm{N}$ reported in Håvik et al. (2017), as well as with the mooring-based annual mean of $-2.5 \pm 0.2 \mathrm{~Sv}$ of Harden et al. (2016) for the EGC south of $68^{\circ} 30^{\prime} \mathrm{N}$. This suggests that the net DSOW transport along the east Greenland shelf break does not vary greatly between NT1 and the Denmark Strait.

Since our definition of the width of the shelf break EGC follows Håvik et al. (2017), a comparison of the transport estimates is possible. Håvik et al. (2017) noted an increase in the shelf break EGC transport from 77.5 to $74^{\circ} \mathrm{N}$. Possibly due to the separation of the EGC into multiple branches south of this latitude, the transport begins to decrease. The transport of the shelf break EGC of their section 10 (for location see Fig. 1) agrees with our estimate for NT1 though our velocities are significantly lower (Fig. 7d). Velocities at their section 9 were closer to our value for NT1 though transport and current width were higher. Velocities and current widths measured by Håvik et al. (2017) were generally higher than those recorded in the present study. This is consistent if one assumes that the increase in isopycnal slope seen between WT1 and NT1 (Sect. 3.3) continues farther to the south. Another explanation could be the denser station spacing in Håvik et al. (2017) $(5-7 \mathrm{~km}$ versus 10 $20 \mathrm{~km}$ in our study). With a denser station spacing it is more likely to sample the location in the EGC with the highest velocity, thus making it more likely to arrive at a higher core velocity. Nevertheless, our study is able to extend the work by Håvik et al. (2017) northward of $79^{\circ} \mathrm{N}$. The definition used for the current width, which is based on a decrease in the core speed to $20 \%$ of its maximum value, gives a southward increase from $20 \mathrm{~km}$ at WT1 to $40 \mathrm{~km}$ at 
NT1. However, this definition, though useful when comparing our data to the results of Håvik et al. (2017) farther south, is not able to capture the actual width of the entire southward flow, which decreases from the broad Arctic Ocean outflow we see at $80.3^{\circ} \mathrm{N}$ to the baroclinic boundary current at $79^{\circ} \mathrm{N}$. This narrowing of the Arctic Ocean outflow to the shelf break EGC at $79^{\circ} \mathrm{N}$ can also be seen in the FESOM velocity fields (Fig. 8a, b) and other model studies (Hattermann et al., 2016; Kawasaki and Hasumi, 2016). It could be argued that the broad Arctic Ocean outflow and northern EGC in modelled velocity fields are an artefact of the multi-year averages portraying the mean of a meandering current. However, comparison with our observations at WT1 and daily averages of model velocities (Movie S1 in the Supplement) suggests that the southward flow north of $79^{\circ} \mathrm{N}$ is indeed broad and not confined to the shelf break.

To better understand the transition of the EGC from a broad barotropic flow to a narrow baroclinic boundary current we examine the different components of the flow. The baroclinic velocity of the southward flow from the simple two-layer estimate (Sect. 2.2) presented above increases from north to south. With the exception of the flow at $79.6^{\circ} \mathrm{N}$ (where the divergence of isopycnals at depth results in a more complicated baroclinic velocity field than captured in our simple two-layer approximation), these baroclinic velocities agree well with the baroclinic velocities calculated from hydrography. Overall, this rough approximation gives some indication that the importance of the baroclinic (i.e. densitydriven) velocity component relative to the barotropic velocity component close to the shelf break increases from north to south. While the baroclinic estimate and absolute velocity components in the southward current at the shelf break show a north to south gradient (the baroclinic velocity increases 6-fold from WT1 to NT1), the barotropic velocity component does not show a clear latitudinal trend. Even though the synoptic study presented here gives an indication that the EGC as a baroclinic boundary current is first observed at $79^{\circ} \mathrm{N}$, continuing southward from there it is only partly able to resolve the transition from a barotropic Arctic outflow north of $80^{\circ} \mathrm{N}$ to the density-driven baroclinic boundary current EGC seen south of $79^{\circ} \mathrm{N}$. However, no previous studies have, to our knowledge, explicitly addressed this question, either for the EGC or more generally for subpolar boundary currents. Further investigations are needed to establish if the local southward current maximum we observed at the shelf break at WT1 is a perennial feature and if either this, the southwestward current associated with the polar front at $0^{\circ} \mathrm{EW}$, or both are the northward continuation of the EGC seen at $79^{\circ} \mathrm{N}$. Multi-year averages from FESOM suggest that continuing north from $79^{\circ} \mathrm{N}$ the density front associated with warm recirculating AW and a band of high southward velocities are located farther east of the east Greenland shelf break (extending east of $0^{\circ} \mathrm{EW}$ north of $80^{\circ} \mathrm{N}$ ) in the deep Fram Strait (Wekerle et al., 2017a, and Fig. 8c, d).

\subsection{Impact of the EGC on the northeast Greenland shelf}

We saw above that AW is far from the shelf break at the Westwind Trough and a broad barotropic flow of Arctic outflow water flows southward between the AW and the trough's mouth. By the time the southward flow reaches the Norske Trough a narrow and baroclinic EGC has formed in which the $\mathrm{AW}$ is mixed in with the ambient AAW, allowing the water $>2{ }^{\circ} \mathrm{C}$ to reach the trough's mouth. Thus AW can enter the Norske Trough but not the Westwind Trough. The depths of the deep temperature maxima, of the $1{ }^{\circ} \mathrm{C}$ isotherm inside the Norske Trough and of the $0.5^{\circ} \mathrm{C}$ isotherm inside the Westwind Trough, observed in this study all agree with the respective depths derived from a compilation of all CTD casts between 1979 and April 2016 (Schaffer et al., 2017). The evolution of the EGC documented above can explain this distribution of Atlantic-derived waters on the east Greenland shelf. Knee Water $(\mathrm{KW})$ is defined as the sharp inflection in $\theta$ space of water close to the freezing point (Bourke et al., 1987) and is formed in the Arctic Ocean by ice-ocean-atmosphere interaction (e.g. Rudels et al., 2005). The distribution of KW is an important indication of the shelf circulation. Both at $79^{\circ} \mathrm{N}$ (not shown) and inside the Westwind Trough (Fig. 6a), $\mathrm{KW}$ is markedly absent at stations close to and on the east Greenland shelf. At NT1 the situation is reversed: KW is only found inshore of the shelf break (Fig. 6c). Observations close to the cavity of the $79 \mathrm{~N}$ Glacier show that the $\mathrm{KW}$ signal found inside the Norske Trough is eroded by isopycnal mixing with glacially modified water originating from both subglacial discharge and submarine melting (Schaffer, 2017). This leads to the hypothesis that KW is brought to the glaciers via the Norske Trough and waters without the KW signature are then exported from the shelf via the Westwind Trough. Thus KW and its absence can be used as a tracer for the shelf circulation. The distribution of KW in the EGC and on the shelf presented here support an anticyclonic circulation in the Atlantic-derived water layer along the trough axes on the northeast Greenland shelf.

Only two of our sections extend far enough onto the east Greenland shelf to show part of the shelf circulation. The surface-intensified current seen on the shelf at $79^{\circ} \mathrm{N}$, between 7.5 and $10^{\circ} \mathrm{W}$ ( -90 and $-20 \mathrm{~km}$, Fig. 3c), only transports small quantities of AW and may thus correspond to the PSW Jet described by Håvik et al. (2017) and seen in the hydrographic data of Nilsson et al. (2008) as far north as $79^{\circ} \mathrm{N}$. The distance of the PSW Jet to the shelf break of $\sim 50 \mathrm{~km}$ in our section and the peak velocity of $-0.24 \mathrm{~m} \mathrm{~s}^{-1}$ agrees with the distance from the shelf break and peak velocity reported in Håvik et al. (2017) between 71 and $68^{\circ}$ N. Our synoptic transport in the PSW Jet $(-1.1 \mathrm{~Sv})$ is only slightly larger than the synoptic transports in the PSW Jet farther south $(-0.54 \pm 0.28$ to $-0.83 \pm 0.27 \mathrm{~Sv}$; Håvik et al., 2017). Unfortunately the sparsity of our shelf data and the velocity uncertainties inside the Westwind Trough do not allow for a 

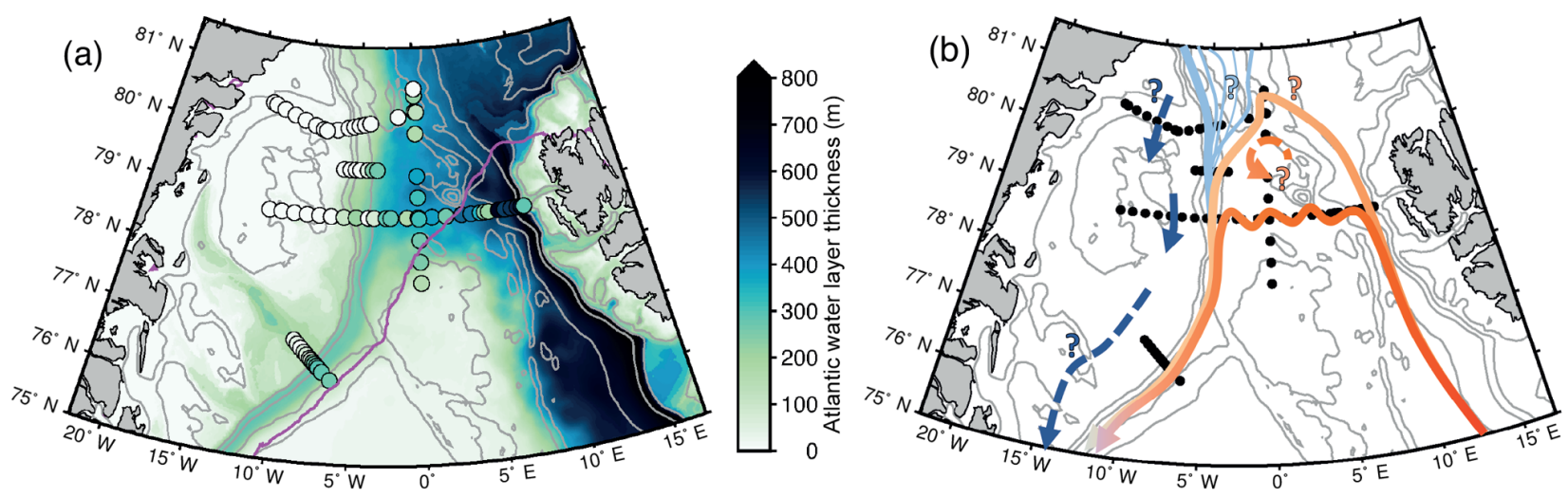

Figure 9. (a) AW-layer thickness given in metres. Shading shows the year-round 2000-2009 average from FESOM and coloured dots show the synoptic station data. Stations at which no AW was measured are shown in white. Thin grey lines represent bathymetry and magenta represents the modelled summer ice edge. (b) The updated circulation scheme is presented. Features we only speculate about are shown dashed and with a question mark.

robust attribution of the cross-sectional flow seen inside the Westwind Trough at $\sim 60 \mathrm{~km}$ (Fig. 3c) as the northern continuation of the PSW Jet seen at $79^{\circ} \mathrm{N}$. The PSW Jet is an important pathway for freshwater transport in the EGC current system (Håvik et al., 2017) and may impact exchanges between the EGC and the marine-terminating glaciers. The presence of a strong density front between the fresh, cold PSW transported in the PSW Jet and the denser, warmer AW and AAW transported at the shelf break would create a barrier between the warmer water and the glacier termini, thus preventing these waters from contributing to submarine melt. The freshwater transport on the Greenland shelf may also provide a feedback mechanism between the glaciers themselves and the ocean, as described in Murray et al. (2010). The authors pose the theory that a decline in the East Greenland Coastal Current, a feature on the southeast Greenland shelf similar to the PSW Jet, can be linked to the influx of warmer water to the glacier termini and rapid speed-up of marine-terminating glaciers. The subsequent influx of meltwater caused a strengthening and cooling of the East Greenland Coastal Current and was followed by a synchronized glacier deceleration. These possible links and processes call for a future detailed study of the northeast Greenland Shelf circulation.

\section{Summary and conclusions}

The maps of the Fram Strait shown in Fig. 9 summarize the view of the recirculation supported by this analysis. The WSC advects AW northward in the eastern Fram Strait where it loses contact with the atmosphere. Recirculating AW subducts underneath PSW and sea ice on its way westward. The ice edge (Fig. 9a) appears, on average, to follow the location of AW subduction and the onset of the recirculation. It thus appears as if the dynamics of the recircula- tion set the seasonally relatively stable ice edge location in the Fram Strait. In our synoptic summer survey along $0^{\circ} \mathrm{EW}$ no AW was found at $80.8^{\circ} \mathrm{N}$, suggesting this latitude as the northern extent of the westward recirculation of AW in the Fram Strait at that time. No AW is found within the Westwind Trough or within $130 \mathrm{~km}$ east of its mouth. AW was first observed near the shelf break at $79.6^{\circ} \mathrm{N}$ and was found inside of the Norske Trough, at a depth that would allow it to propagate to the terminus of the $79 \mathrm{~N}$ Glacier. Moreover, the deep $\theta$ maximum was above $2^{\circ} \mathrm{C}$ at all stations sampled at $76.5^{\circ} \mathrm{N}$ (at the mouth of the Norske Trough), indicating that, at the depth of the deep temperature maximum, AAW had been completely mixed in with the recirculating AW. Figure 9a shows that, allowing for the synoptic variations which of course do not show up in the long-term average of model output, the modelled AW layer thickness and our summer synoptic observations agree reasonably well in the southeastern Fram Strait. The most striking difference and something that should be investigated in the future is that water warmer than $2{ }^{\circ} \mathrm{C}$ spreads farther northwestward in the model than observed there. It is evident from the synoptic CTD sections along $79^{\circ} \mathrm{N}$ in Marnela et al. (2013), in Langehaug and Falck (2012) and in the present study, as well as in the moored measurements of von Appen et al. (2016), that the synoptic view of $79^{\circ} \mathrm{N}$ differs substantially from the long-term mooring (e.g. Beszczynska-Möller et al., 2012) and model averages (e.g. Wekerle et al., 2017a) which make the velocity field appear rather smooth (Fig. 4b). In contrast, Fig. $3 \mathrm{c}$ shows a qualitative picture of instantaneous eddy variability. It is important to consider the highly variable structure of the flow field in order to reconcile measurements that at first seem counter-intuitive, such as northward flow in areas where the EGC is expected, with the overall circulation in the Fram Strait. The daily velocity averages (Movie S1 in the Supplement) and long-term EKE averages 
from FESOM (Fig. 4c) show that the very dynamic velocity structure at $79^{\circ} \mathrm{N}$ is not an artefact of our measurement technique. It, rather, is representative of the synoptic eddy field, a view that is typically lost in depictions of long-term (or even monthly) averages. The same is true for the surfaceintensified current on the shelf (the PSW Jet) that is seen in the synoptic section. This, too, is not discernible in the multiyear average of the FESOM velocity field though it is sometimes present in the daily averages. We think that it is representative that in our synoptic sections the boundary currents (WSC and EGC) instantaneously appear weaker than the eddies present in the Fram Strait. This is supported by longterm velocity measurements showing synoptic velocities in the Fram Strait, likely associated with eddies, that are significantly higher than the time-averaged velocity in the WSC (von Appen et al., 2016). The synoptic view presented here is also important for understanding the manifold processes, such as salt and heat transport to the central Fram Strait and nutrient exchange between the surface layer and deeper water masses, that are mediated by small-scale features such as eddies. The small scale and highly variable structure of the velocity field in the Fram Strait makes it essential to conduct both hydrographic surveys and model runs at an appropriate resolution to prevent aliasing. At the same time, it needs to be considered that any particular water sample taken in the Fram Strait derives from this eddy field and may either have originated from inside or outside of transient eddies.

The Arctic Ocean outflow region between the northeast Greenland shelf and $0^{\circ} \mathrm{EW}$ is evident as a broad barotropic flow both in our synoptic section at $80.3^{\circ} \mathrm{N}$ (Fig. 3c) and in the velocity field from FESOM (Fig. 4b). From examination of the modelled velocity output we hypothesize that this Arctic Ocean outflow is at least partly topographically steered (see Fig. 7 in Wekerle et al., 2017a). We propose that the evolution of the barotropic Arctic Ocean outflow to the baroclinic EGC is driven by the recirculation of AW in the Fram Strait. As the recirculating AW reaches ever closer to the east Greenland shelf break, the Arctic Ocean outflow is restricted to an increasingly narrow band along the shelf break. At the same time the density difference between recirculating AW and waters of Arctic origin drives a baroclinic current. In the northern Fram Strait, where the maximum westward extent of AW is located in the central Fram Strait close to $0^{\circ} \mathrm{EW}$, a baroclinic current associated with the polar front and the ice edge was described to merge with the EGC farther south (Schlichtholz and Houssais, 1999). This current was described as part of the EGC by Paquette et al. (1985). Farther south, the baroclinic boundary current EGC was also associated with the polar front, there located at the east Greenland shelf break as recirculating AW has spread farther west in the Fram Strait. Here we argue that the EGC, Arctic Ocean outflow and AW recirculation are not separate but that the latter two combine to form the EGC. In a more global perspective, there are other boundary currents which do not follow a shelf break in their upstream part; these have to join the shelf break somehow. For example, different idealized models (Lighthill, 1969; Endoh, 1973; Suginohara, 1980) showed that barotropic and baroclinic Rossby waves from the ocean interior can explain the formation of western boundary currents. Seemingly eddies may play the same role as Rossby waves. We further presume that eddies in the Fram Strait transport warm water to the western boundary which increases the along-boundary transport. Aspects of the circulation that require further study are the northern extent of the recirculation; the spatial distribution of AW between the shelf break near the Westwind Trough and $0^{\circ} \mathrm{EW}$; the circulation structure in the central Fram Strait north of $79^{\circ} \mathrm{N}$, with the possible role of the Molloy Hole; and the shelf circulation. A better knowledge of these would allow further reaching questions to be studied, e.g. the nutrient and freshwater fluxes to and from the Arctic, the role of the Nordic Seas and Arctic Ocean in deep water formation, or the effect of the shelf circulation on submarine melt of Greenland glaciers. Ultimately all of these components link in with the larger question of how the Arctic is influenced by the changing climate. To answer the question of whether the EGC exists in the northern Fram Strait, we note that the baroclinic boundary current does not exist in the northern Fram Strait. Here, we take southward flow in a baroclinic boundary current along the shelf break as a defining feature of the EGC. By this definition, based on our evidence, we conclude that the EGC does not exist north of $79^{\circ} \mathrm{N}$. It rather appears that the southward transport in the northern Fram Strait is Arctic Ocean outflow.

Code and data availability. Data are available under the following references: CTD casts (https://doi.org/10.1594/PANGAEA. 871030, Kanzow et al., 2017a; https://doi.org/10.1594/PANGAEA. 871025, Kanzow et al., 2017b), LADCP (https://doi.org/10.1594/ PANGAEA.870995, von Appen et al., 2017), and VMADCP (https://doi.org/10.1594/PANGAEA.867798, Kanzow and Witte, 2016). The source code of the FESOM model is available under Wang et al. (2017) and the model output used is available under Wekerle et al. (2017b). The CORE.v2 dataset (Large and Yeager, 2009) is available at https://data1.gfdl.noaa. gov/nomads/forms/core/COREv2.html. The RTopo-2 data set is available in full and in regional subsets in NetCDF format from the PANGAEA database at https://doi.pangaea.de/10.1594/ PANGAEA.856844 (Schaffer and Timmermann, 2016), the IBCAO Version 3 bathymetry is available at https://www.ngdc.noaa.gov/ mgg/bathymetry/arctic/ibcaoversion3.html (Jakobsson et al., 2012). The AOTIM-5 model is available at https://www.esr.org/research/ polar-tide-models/list-of-polar-tide-models/aotim-5/ (Padman and Erofeeva, 2004).

Supplement. The supplement related to this article is available online at: https://doi.org/10.5194/os-14-1147-2018-supplement. 
Author contributions. CW led the analysis of the model output. MER led the analysis of the data and interpretation of the data and model output, as well as the write up of the paper. All authors contributed to each of these points.

Competing interests. The authors declare that they have no conflict of interest.

Acknowledgements. We wish to thank the captain and crew of RV Polarstern. We would also like to thank Torsten Kanzow and Janin Schaffer for their contributions to the comprehensive dataset that this study is based on. Further we thank Janin Schaffer for the kind use of the map of the Fram Strait in Fig. 1 and for useful discussions on glacier-trough exchange. Support for this study was provided by the Deutsche Forschungsgemeinschaft (DFG) through the grant OGreen79 as part of the Special Priority Program (SPP)-1889 "Regional Sea Level Change and Society" (SeaLevel) and the Helmholtz Infrastructure Initiative FRAM. Data for this study was collected under grant number AWI-PS100_01.

The article processing charges for this open-access

publication were covered by a Research

Centre of the Helmholtz Association.

Edited by: Matthew Hecht

Reviewed by: two anonymous referees

\section{References}

Aagaard, K. and Coachman, L. K.: The East Greenland Current north of Denmark Strait: Part I, Arctic, 21, 181-200, 1968.

Aagaard, K., Foldvik, A., and Hillman, S.: The West Spitsbergen Current: disposition and water mass transformation, J. Geophys. Res.-Oceans, 92, 3778-3784, 1987.

Aksenov, Y., Bacon, S., Coward, A. C., and Nurser, A. G.: The North Atlantic inflow to the Arctic Ocean: High-resolution model study, J. Marine Syst., 79, 1-22, 2010.

Aksenov, Y., Ivanov, V. V., Nurser, A., Bacon, S., Polyakov, I. V., Coward, A. C., Naveira-Garabato, A. C., and BeszczynskaMöller, A.: The Arctic circumpolar boundary current, J. Geophys. Res.-Oceans, 116, C9, 2011.

Beszczynska-Möller, A., Fahrbach, E., Schauer, U., and Hansen, E.: Variability in Atlantic water temperature and transport at the entrance to the Arctic Ocean, 1997-2010, ICES J. Mar. Sci., 69, 852-863, 2012.

Bourke, R. H., Newton, J. L., Paquette, R. G., and Tunnicliffe, M. D.: Circulation and water masses of the East Greenland Shelf, J. Geophys. Res.-Oceans, 92, 6729-6740, 1987.

Dai, A., Qian, T., Trenberth, K. E., and Milliman, J. D.: Changes in continental freshwater discharge from 1948 to 2004, J. Climate, 22, 2773-2792, 2009.

Danilov, S., Wang, Q., Timmermann, R., Iakovlev, N., Sidorenko, D., Kimmritz, M., Jung, T., and Schröter, J.: Finite-Element Sea Ice Model (FESIM), version 2, Geosci. Model Dev., 8, 17471761, https://doi.org/10.5194/gmd-8-1747-2015, 2015. de Steur, L., Hansen, E., Gerdes, R., Karcher, M., Fahrbach, E., and Holfort, J.: Freshwater fluxes in the East Greenland Current: A decade of observations, Geophys. Res. Lett., 36, https://doi.org/10.1029/2009GL041278, 2009.

de Steur, L., Hansen, E., Mauritzen, C., Beszczynska-Möller, A., and Fahrbach, E.: Impact of recirculation on the East Greenland Current in Fram Strait: Results from moored current meter measurements between 1997 and 2009, Deep-Sea Res., 92, 26-40, 2014.

Endoh, M.: A numerical experiment on the variations of western boundary currents: Part I. Formation of western boundary currents, J. Oceanogr., 29, 16-27, 1973.

Fahrbach, E., Meincke, J., Østerhus, S., Rohardt, G., Schauer, U., Tverberg, V., and Verduin, J.: Direct measurements of volume transports through Fram Strait, Polar Res., 20, 217-224, 2001.

Falck, E., Kattner, G., and Budéus, G.: Disappearance of Pacific water in the northwestern Fram Strait, Geophys. Res. Lett., 32, https://doi.org/10.1029/2005GL023400, 2005.

Fieg, K., Gerdes, R., Fahrbach, E., Beszczynska-Möller, A., and Schauer, U.: Simulation of oceanic volume transports through Fram Strait 1995-2005, Ocean Dynam., 60, 491-502, 2010.

Gascard, J.-C., Kergomard, C., Jeannin, P.-F., and Fily, M.: Diagnostic study of the Fram Strait marginal ice zone during summer from 1983 and 1984 Marginal Ice Zone Experiment Lagrangian observations, J. Geophys. Res.-Oceans, 93, 3613-3641, 1988.

Gascard, J.-C., Richez, C., and Rouault, C.: New insights on largescale oceanography in Fram Strait: The West Spitsbergen Current, Arctic Oceanography: Marginal Ice Zones and Continental Shelves, American Geophysical Union (AGU), edited by: Smith, W. O. and Grebmeir, J. M., 131-182, 1995.

Hanzlick, D. J.: The West Spitsbergen Current: Transport, Forcing, and Variability., PhD thesis, University of Washington, Washington, USA, 1983.

Harden, B. E., Pickart, R. S., Valdimarsson, H., Våge, K., de Steur, L., Richards, C., Bahr, F., Torres, D., Børve, E., Jónsson, S., Macrander, A., Østerhus, S., Håvik, L., and Hattermann, T.: Upstream sources of the Denmark Strait Overflow: Observations from a high-resolution mooring array, Deep-Sea Res. Pt. I, 112, 94-112, 2016.

Hattermann, T., Isachsen, P. E., von Appen, W.-J., Albretsen, J., and Sundfjord, A.: Eddy-driven recirculation of Atlantic Water in Fram Strait, Geophys. Res. Lett., 43, 1-9, 2016.

Håvik, L., Pickart, R., Våge, K., Torres, D., Thurnherr, A., Beszczynska-Möller, A., Walczowski, W., and von Appen, W.J.: Evolution of the East Greenland Current from Fram Strait to Denmark Strait: Synoptic measurements from summer 2012, J. Geophys. Res.-Oceans, 2017.

Hunke, E. and Dukowicz, J.: The Elastic-Viscous-Plastic Sea Ice Dynamics Model in General Orthogonal Curvilinear Coordinates on a Sphere-Incorporation of Metric Term, Mon. Weather Rev., 130, 1848-1865, 2001.

Ilicak, M., Drange, H., Wang, Q., et al.: An assessment of the Arctic Ocean in a suite of interannual CORE-II simulations, Part II: Liquid freshwater, Ocean Model., 99, 86-109, 2016.

Jakobsson, M., Mayer, L., Coakley, B., et al.: The international bathymetric chart of the Arctic Ocean (IBCAO) version 3.0, Geophys. Res. Lett., 39, https://doi.org/10.1029/2012GL052219, 2012. 
Johannessen, J., Johannessen, O., Svendsen, E., Shuchman, R., Manley, T., Campbell, W., Josberger, E., Sandven, S., Gascard, J., Olaussen, T., Davidson, K., and Van Leer, J.: Mesoscale eddies in the Fram Strait marginal ice zone during the 1983 and 1984 Marginal Ice Zone Experiments, J. Geophys. Res.-Oceans, 92, 6754-6772, 1987.

Kanzow, T.: The Expedition PS100 of the Research Vessel POLARSTERN to the Fram Strait in 2016, Tech. Rep. 705, AlfredWegener-Institut, Helmholtz-Zentrum für Polar- und Meeresforschung, reports on Polar and Marine Research, available at: http://hdl.handle.net/10013/epic.50192 (last access: 20 September 2018), 2017.

Kanzow, T. and Witte, H.: Raw data of continuous VMADCP (vessel-mounted Acoustic Doppler Current Profiler) profile during POLARSTERN cruise PS100 (ARK-XXX/2), https://doi.org/10.1594/PANGAEA.867798, 2016.

Kanzow, T., von Appen, W.-J., Schaffer, J., Köhn, E., Tsubouchi, T., Wilson, N., Lodeiro, P. F., Evers, F., and Wisotzki, A.: Physical oceanography measured with ultra clean CTD/Watersamplersystem during POLARSTERN cruise PS100 (ARK-XXX/2), https://doi.org/10.1594/PANGAEA.871030, 2017a.

Kanzow, T., von Appen, W.-J., Schaffer, J., Köhn, E., Tsubouchi, T., Wilson, N., and Wisotzki, A.: Physical oceanography measured with CTD/Large volume Watersamplersystem during POLARSTERN cruise PS100 (ARK-XXX/2), https://doi.org/10.1594/PANGAEA.871025, 2017b.

Karcher, M. J., Gerdes, R., Kauker, F., and Köberle, C.: Arctic warming: Evolution and spreading of the 1990s warm event in the Nordic seas and the Arctic Ocean, J. Geophys. Res.-Oceans, 108, https://doi.org/10.1029/2001JC001265, 2003.

Kawasaki, T. and Hasumi, H.: The inflow of Atlantic water at the Fram Strait and its interannual variability, J. Geophys. Res.Oceans, 121, 502-519, 2016.

Koenig, Z., Provost, C., Senne'chael, N., Garric, G., and Gascard, J.: The Yermak Pass Branch: A major pathway for the Atlantic Water north of Svalbard, J. Geophys. Res.-Oceans, 122, 9332 9349, https://doi.org/10.1002/2017JC013271, 2017.

Langehaug, H. R. and Falck, E.: Changes in the properties and distribution of the intermediate and deep waters in the Fram Strait, Prog. Oceanogr., 96, 57-76, 2012.

Large, W. G. and Yeager, S.: The global climatology of an interannually varying air-sea flux data set, Clim. Dynam., 33, 341-364, 2009.

Lighthill, M. J.: Dynamic response of the Indian Ocean to onset of the southwest monsoon, Philos. T. R. Soc, A, 265, 45-92, 1969.

Manley, T.: Branching of Atlantic Water within the GreenlandSpitsbergen Passage: An estimate of recirculation, J. Geophys. Res.-Oceans, 100, 20627-20634, 1995.

Marnela, M., Rudels, B., Olsson, K. A., Anderson, L. G., Jeansson, E., Torres, D. J., Messias, M.-J., Swift, J. H., and Watson, A. J.: Transports of Nordic Seas water masses and excess SF 6 through Fram Strait to the Arctic Ocean, Prog. Oceanogr., 78, 1-11, 2008.

Marnela, M., Rudels, B., Houssais, M.-N., Beszczynska-Möller, A., and Eriksson, P. B.: Recirculation in the Fram Strait and transports of water in and north of the Fram Strait derived from CTD data, Ocean Sci., 9, 499-519, https://doi.org/10.5194/os-9-4992013, 2013.

Maslowski, W., Marble, D., Walczowski, W., Schauer, U., Clement, J. L., and Semtner, A. J.: On climatological mass, heat, and salt transports through the Barents Sea and Fram Strait from a panArctic coupled ice-ocean model simulation, J. Geophys. Res.Oceans, 109, https://doi.org/10.1029/2001JC001039, 2004.

Mauritzen, C.: Production of dense overflow waters feeding the North Atlantic across the Greenland-Scotland Ridge. Part 1: Evidence for a revised circulation scheme, Deep-Sea Res. Pt. I, 43, 769-806, 1996.

Moore, R. and Wallace, D.: A relationship between heat transfer to sea ice and temperature-salinity properties of Arctic Ocean waters, J. Geophys. Res., 93, 565-571, 1988.

Murray, T., Scharrer, K., James, T., Dye, S., Hanna, E., Booth, A., Selmes, N., Luckman, A., Hughes, A., Cook, S., and Huybrechts, P.: Ocean regulation hypothesis for glacier dynamics in southeast Greenland and implications for ice sheet mass changes, J. Geophys. Res.-Earth, 115, https://doi.org/10.1029/2009JF001522, 2010.

Nilsson, J., Björk, G., Rudels, B., Winsor, P., and Torres, D.: Liquid freshwater transport and Polar Surface Water characteristics in the East Greenland Current during the AO-02 Oden expedition, Prog. Oceanogr., 78, 45-57, 2008.

Padman, L. and Erofeeva, S.: A barotropic inverse tidal model for the Arctic Ocean, Geophys. Res. Lett., 31, https://doi.org/10.1029/2003GL019003, 2004.

Paquette, R. G., Bourke, R. H., Newton, J. F., and Perdue, W. F.: The East Greenland polar front in autumn, J. Geophys. Res.-Oceans, 90, 4866-4882, 1985.

Parkinson, C. and Washington, W.: A Large-Scale Numerical Model of Sea Ice, J. Geophys. Res., 84, 311-337, https://doi.org/10.1029/JC084iC01p00311, 1979.

Perkin, R. and Lewis, E.: Mixing in the West Spitsbergen Current, J. Phys. Oceanogr., 14, 1315-1325, 1984.

Polyakov, I. V., Alexeev, V. A., Ashik, I. M., Bacon, S., Beszczynska-M"øller, A., Carmack, E. C., Dmitrenko, I. A., Fortier, L., Gascard, J.-C., Hansen, E., Hölemann, J., Ivanov, V. V., Kikuchi, T., Kirillov, S., Lenn, Y.-D., McLaughlin, F. A., Piechura, J., Repina, I., Timokhov, L. A., Walczowski, W., and Woodgate, R.: Fate of early 2000s Arctic warm water pulse, B. Am. Meteorol. Soc., 92, 561-566, 2011.

Quadfasel, D., Gascard, J.-C., and Koltermann, K.-P.: Large-scale oceanography in Fram Strait during the 1984 Marginal Ice Zone Experiment, J. Geophys. Res.-Oceans, 92, 6719-6728, 1987.

Richter, M. E.: Fram Strait recirculation and the East Greenland Current: Spatial structure north of $79^{\circ} \mathrm{N}$, Master's thesis, University of Bremen, Bremen, Germany, available at: http://hdl.handle. net/10013/epic.52015 (last access: 20 September 2018), 2017.

Rudels, B.: On the mass balance of the Polar Ocean, with special emphasis on the Fram Strait, vol. 188 of Skrifter, Norsk Polarinstitutt, Oslo, Norway, 1987.

Rudels, B., Anderson, L., and Jones, E.: Formation and evolution of the surface mixed layer and halocline of the Arctic Ocean, J. Geophys. Res.-Oceans, 101, 8807-8821, 1996.

Rudels, B., Fahrbach, E., Meincke, J., Budéus, G., and Eriksson, P.: The East Greenland Current and its contribution to the Denmark Strait overflow, ICES J. Mar. Sci. 59, 1133-1154, 2002.

Rudels, B., Björk, G., Nilsson, J., Winsor, P., Lake, I., and Nohr, C.: The interaction between waters from the Arctic Ocean and the Nordic Seas north of Fram Strait and along the East Greenland Current: results from the Arctic Ocean-02 Oden expedition, J. Marine Syst., 55, 1-30, 2005. 
Rudels, B., Korhonen, M., Budéus, G., Beszczynska-Möller, A., Schauer, U., Nummelin, A., Quadfasel, D., and Valdimarsson, H.: The East Greenland Current and its impacts on the Nordic Seas: observed trends in the past decade, ICES J. Mar. Sci., 69, 841-851, 2012.

Rudels, B., Korhonen, M., Schauer, U., Pisarev, S., Rabe, B., and Wisotzki, A.: Circulation and transformation of Atlantic water in the Eurasian Basin and the contribution of the Fram Strait inflow branch to the Arctic Ocean heat budget, Prog. Oceanogr., 132, 128-152, 2015.

Ryder, C.: Den Østgrønlandske expedition udført i aarene 1891-92, $\mathrm{V}$, hydrografiske undersøgelser, in: Meddelelser om Grønland, Commissionen for Ledelsen af de geologiske og geographiske Undersøgelser i Grønland, 17, 191-221, 1895.

Schaffer, J.: Ocean impact on the 79 North Glacier, Northeast Greenland, $\mathrm{PhD}$ thesis, University of Bremen, Bremen, Germany, available at: http://nbn-resolving.de/urn:nbn:de:gbv: 46-00106281-12 (last access: 20 September 2018), 2017.

Schaffer, J. and Timmermann, R.: Greenland and Antarctic ice sheet topography, cavity geometry, and global bathymetry (RTopo2), links to NetCDF files, PANGAEA, https://doi.org/10.1594/ PANGAEA.856844 (last access: 24 September 2018), 2016.

Schaffer, J., Timmermann, R., Arndt, J. E., Kristensen, S. S., Mayer, C., Morlighem, M., and Steinhage, D.: A global, highresolution data set of ice sheet topography, cavity geometry, and ocean bathymetry, Earth Syst. Sci. Data, 8, 543-557, https://doi.org/10.5194/essd-8-543-2016, 2016.

Schaffer, J., von Appen, W.-J., Dodd, P. A., Hofstede, C., Mayer, C., de Steur, L., and Kanzow, T.: Warm water pathways toward Nioghalvfjerdsfjorden Glacier, Northeast Greenland, J. Geophys. Res.-Oceans, 122, 4004-4020, 2017.

Schauer, U., Muench, R. D., Rudels, B., and Timokhov, L.: Impact of eastern Arctic shelf waters on the Nansen Basin intermediate layers, J. Geophys. Res., 102, 3371-3382, 1997.

Schlichtholz, P. and Houssais, M.-N.: An inverse modeling study in Fram Strait. Part I: dynamics and circulation, Deep-Sea Res. Pt. II, 46, 1083-1135, 1999.

Smith, W. and Wessel, P.: Gridding with continuous curvature splines in tension, Geophysics, 55, 293-305, 1990.

Suginohara, N.: Effects of bottom topography and density stratification on the formation of western boundary currents, J. Oceanogr., 35, 224-232, 1980.

Sutherland, D. A.: The East Greenland Coastal Current: its structure, variability, and large-scale impact, $\mathrm{PhD}$ thesis, MIT/WHOI Joint Program, Massachusetts, USA, 161 pp., 2008.

Teigen, S. H., Nilsen, F., Skogseth, R., and Gjevik, B.: Barotropic instability in the West Spitsbergen Current, J. Geophys. Res., 115, 35-52, 2010.

Teigen, S. H., Nilsen, F., Skogseth, R., Gjevik, B., and Beszczynska-Möller, A.: Baroclinic instability in the West Spitsbergen Current, J. Geophys. Res.-Oceans, 116, https://doi.org/10.1029/2011JC006974, 2011.
Thurnherr, A.: A practical assessment of the errors associated with full-depth LADCP profiles obtained using Teledyne RDI Workhorse acoustic Doppler current profilers, J. Atmos. Ocean. Tech., 27, 1215-1227, 2010.

Våge, K., Pickart, R. S., Spall, M. A., Moore, G., Valdimarsson, H., Torres, D. J., Erofeeva, S. Y., and Nilsen, J. E. Ø.: Revised circulation scheme north of the Denmark Strait, Deep-Sea Res. Pt. I, 79, 20-39, 2013.

von Appen, W.-J., Schauer, U., Somavilla, R., Bauerfeind, E., and Beszczynska-Möller, A.: Exchange of warming deep waters across Fram Strait, Deep-Sea Res., 103, 86-100, 2015.

von Appen, W.-J., Schauer, U., Hattermann, T., and BeszczynskaMöller, A.: Seasonal cycle of mesoscale instability of the West Spitsbergen Current, J. Phys. Oceanogr., 46, 1231-1254, 2016.

von Appen, W.-J., Kanzow, T., and Schaffer, J.: Lowered Acoustic Doppler Current Profiler (LADCP) raw data collected during POLARSTERN cruise PS100, https://doi.org/10.1594/PANGAEA.870995, 2017.

Walczowski, W., Beszczynska-Möller, A., Wieczorek, P., Merchel, M., and Grynczel, A.: Oceanographic observations in the Nordic Sea and Fram Strait in 2016 under the IOPAN long-term monitoring program AREX, Oceanologia, 59, 187-194, 2017.

Wang, Q., Danilov, S., Sidorenko, D., Timmermann, R., Wekerle, C., Wang, X., Jung, T., and Schröter, J.: The Finite Element Sea Ice-Ocean Model (FESOM) v.1.4: formulation of an ocean general circulation model, Geosci. Model Dev., 7, 663693, https://doi.org/10.5194/gmd-7-663-2014, 2014.

Wang, Q., Wekerle, C., Danilov, S., Wang, X., and Jung, T.: The Finite-Element Sea ice-Ocean Model (FESOM) (Version 2), Zenodo, http://doi.org/10.5281/zenodo.1116851 (last access: 24 September 2018), 2017.

Wekerle, C., Wang, Q., von Appen, W.-J., Danilov, S., SchourupKristensen, V., and Jung, T.: Eddy-Resolving Simulation of the Atlantic Water Circulation in the Fram Strait With Focus on the Seasonal Cycle, J. Geophys. Res.-Oceans, 122, 8385-8405, 2017a.

Wekerle, C., Wang, Q., von Appen, W.-J., Danilov, S., SchourupKristensen, V., and Jung, T.: Eddy-permitting and eddyresolving simulations of the Fram Strait ocean dynamics with the Finite-Element Sea-Ice Ocean Model (FESOM), links to NetCDF files, PANGAEA, https://doi.org/10.1594/PANGAEA. 880569 (last access: 24 September 2018), 2017b.

Woodgate, R. A., Fahrbach, E., and Rohardt, G.: Structure and transports of the East Greenland Current at $75^{\circ} \mathrm{N}$ from moored current meters, J. Geophys. Res.-Oceans, 104, 18059-18072, 1999. 